\title{
Calving event detection by observation of seiche effects on the Greenland fjords
}

\author{
Fabian WALTER, ${ }^{1,2}$ Marco OLIVIERI, ${ }^{3}$ John F. CLINTON ${ }^{1}$ \\ ${ }^{1}$ Swiss Seismological Service, ETH Zürich, Zürich, Switzerland \\ E-mail: fwalter@ucsd.edu \\ ${ }^{2}$ Laboratory of Hydraulics, Hydrology and Glaciology, ETH Zürich, Zürich, Switzerland \\ ${ }^{3}$ Istituto Nazionale di Geofisica e Vulcanologia, Bologna, Italy
}

\begin{abstract}
With mass loss from the Greenland ice sheet accelerating and spreading to higher latitudes, the quantification of mass discharge in the form of icebergs has recently received much scientific attention. Here we make use of very low-frequency $(0.001-0.01 \mathrm{~Hz})$ seismic data from three permanent broadband stations installed in the summers of 2009-10 in northwest Greenland in order to monitor local calving activity. At these frequencies, calving seismograms are dominated by a tilt signal produced by local ground flexure in response to fjord seiching generated by major iceberg calving events. A simple triggering algorithm is proposed to detect calving events from large calving fronts with potentially no user interaction. Our calving catalogue identifies spatial and temporal differences in calving activity between Jakobshavn Isbræ and glaciers in the Uummannaq district $\sim 200 \mathrm{~km}$ to the north. The Uummannaq glaciers show clear seasonal fluctuations in seiche-based calving detections as well as seiche amplitudes. In contrast, the detections at Jakobshavn Isbræ show little seasonal variation, which may be evidence for an ongoing transition to winter calving activity. The results offer further evidence that seismometers can provide efficient and inexpensive monitoring of calving fronts.
\end{abstract}

\section{INTRODUCTION}

In recent years, the accelerating mass loss of the Greenland ice sheet has raised global sea level by $0.67 \mathrm{~mm} \mathrm{a}^{-1}$ (Spada and others, 2012). It is equally divided between negative surface mass balance and dynamic discharge to the ocean, also known as 'dynamic mass loss' (e.g. Rignot and others, 2008, 2011; Van den Broeke and others, 2009; Khan and others, 2010). Discharge occurs mainly through outlet glaciers, whose flow velocities often exceed $3 \mathrm{~km} \mathrm{a}^{-1}$ (e.g. Joughin and others, 2010). The dynamic mass loss component has recently received much attention, as major outlet glaciers throughout Greenland started accelerating in the early 2000s. Although this phenomenon initiated at the more southerly outlet glaciers, it now affects outlet glaciers at all latitudes (e.g. Rignot and Kanagaratnam, 2006; Pritchard and others, 2009).

At the termini of Greenland's outlet glaciers, mass discharge occurs mainly through iceberg calving, although at least in some regions submarine melting may be responsible for similar amounts of mass loss (Rignot and others, 2010). In an effort to understand and quantify Greenland's recent mass loss, iceberg calving has become the focus of vigorous glaciological investigation. GPS measurements (Amundson and others, 2008; Nettles and others, 2008) and theoretical studies (Thomas, 2004; Lüthi, 2009; Nick and others, 2009) show that outlet glaciers can accelerate in response to large calving events. Consequently, calving processes may also have a direct effect on ice-sheet stability. Indeed, there exists strong evidence that despite significant regional variability (Moon and others, 2012), much of the recent episodic discharge increase in Greenland was triggered at calving fronts when fjord waters underwent transient warming (Holland and others, 2008; Murray and others, 2010; Rignot and others, 2012).

Despite its important role in glacier and ice-sheet mass balance, iceberg calving is still poorly understood. It remains a considerable challenge to incorporate the relevant boundary conditions (e.g. water and air temperatures, proglacial water depth, strain rates near the calving front, and fracture state of the terminus) into a 'universal calving law' (Benn and others, 2007; Alley and others, 2008; Amundson and Truffer, 2010; Bassis, 2011). One obstacle facing iceberg calving studies is the lack of supporting data. Satellite images detect and quantify calving events at limited temporal and spatial resolution (e.g. Joughin and others, 2008a). Direct visual observations using time-lapse cameras can provide impressively complete catalogues of calving events (e.g. O'Neel and others, 2007; Köhler and others, 2011). However, these observations often come at high costs, are prone to subjective judgment of the observer, are limited to the seasons with daylight and provide only rough estimates of calving volumes.

Seismic monitoring of iceberg calving activity is an attractive alternative to direct observations, as large calving events can generate energy across a broad frequency range (e.g. O'Neel and others, 2007, 2010; Amundson and others, 2008, 2012a). Use of seismic signals to monitor calving activity at various scales has previously been documented. Initial studies using sensors with limited frequency bands focused on high-frequency components $(>1 \mathrm{~Hz})$ of regional calving seismograms (e.g. Qamar, 1988). More recently, such high-frequency signals with narrowband character $(1-5 \mathrm{~Hz})$ have been associated with interactions between detaching icebergs and the sea surface (Bartholomaus and others, 2012) as well as various englacial fracture mechanisms that are active during calving events (e.g. O'Neel and Pfeffer, 2007; Amundson and others, 2008; Richardson and others, 2010).

The deployment of broadband seismometers has facilitated the observation of the broadband nature of signals produced by calving events. 'Glacial earthquakes' (Ekström and others, 2003; Tsai and Ekström, 2007; Joughin and others, 2008a; Larmat and others, 2008; Nettles and others, 
2008; Nettles and Ekström, 2010) are generated by major calving events. They are identifiable on global seismic networks via detection of low-frequency (35-150 s) surface waves generated during iceberg detachment. Recent work on records at both teleseismic and local distances indicates the source mechanism of these events is most likely collision forces between detaching icebergs and the glacier terminus or fjord bottom (Amundson and others, 2008; Tsai and others, 2008; Nettles and Ekström, 2010; Walter and others, 2012). The glacial earthquakes detected at teleseismic distances have a surface wave amplitude equivalent to $\sim$ M5 tectonic earthquakes. Most glacial earthquakes are generated during calving events in Greenland; however, Antarctic events have also been confirmed (Nettles and Ekström, 2010; Chen and others, 2011). Seasonal and secular changes in glacial earthquake detections have been associated with changes in dynamics of Greenland outlet glaciers (Ekström and others, 2006; Joughin, 2006).

Despite these promising results, there remain open questions about the completeness of calving catalogues generated by 'glacial earthquake', or teleseismic surface wave detection, particularly since only some classes of largescale calving events appear to generate significant lowfrequency surface wave energy. Specifically, Nettles and Ekström (2010) suggested that only capsizing icebergs appear to generate observable low-frequency surface wave energy, whereas tabular, non-capsizing icebergs can calve 'quietly'. Similarly, they note that relatively few glacial earthquakes can be attributed to floating ice tongues, which suggests that coupling of the terminus to the solid Earth is essential for surface wave generation. Consequently, the glacial earthquake catalogue may not reflect the full extent of seasonal variations in calving activity, because large, tabular and smaller capsizing icebergs typically can calve at different times of the year (Amundson and others, 2010). Furthermore, the single-force source conventionally used to model glacial earthquakes (e.g. Ekström and others, 2003; Tsai and Ekström, 2007) provides a force amplitude, whose relationship with iceberg volume is not fully understood (Amundson and others, 2012b; Walter and others, 2012). Correspondingly, the upper limit for glacial earthquake size indicated by surface wave magnitudes (Nettles and Ekström, 2010) may not only be the result of a limit of glacier calving volume.

Normal modes of proglacial fjord waters, which are excited as icebergs detach from glacier termini, are another type of calving-generated signal. The low-frequency $(<0.01 \mathrm{~Hz})$ signals from such 'seiches' can be recorded by seismometers in response to major calving events at Jakobshavn Isbræ, one of Greenland's largest ice streams (Amundson and others, 2012a). In other closed and semiclosed water bodies, such as lakes (e.g. Forel, 1904) and harbours (e.g. Miles, 1974), seiches are commonly induced by winds. Seiches triggered through earthquakes (Kvale, 1955; Ichinose and others, 2000), landslides (Bondevik and others, 2005) and ship traffic (McNamara and others, 2011) have also been reported.

In the present paper we show that, using data from three broadband stations in the vicinity of fjords into which calving occurs in Greenland, the long-period component of the seismic recordings can effectively be used to detect seiches. We analyse the performance of a purely automatic detection algorithm and discuss result improvement when some user interaction is added. We corroborate our detections using local tide gauge records, time-lapse photographs, satellite images and the teleseismic glacial earthquake catalogue (Veitch and Nettles, 2012). Furthermore, we analyse our derived catalogue to discuss calving activity of several Greenlandic glaciers. Due to their remote locations, the dynamics of these glaciers are difficult to study with in situ field techniques.

\section{SEISMIC AND FJORD PRESSURE DATA}

The Greenland Ice Sheet Monitoring Network (GLISN; http:// glisn.info/; Dahl-Jensen and others, 2010; Husen and others, 2010) is a recent broadband seismic infrastructure in and around Greenland (Fig. 1). GLISN is a joint collaboration between the USA, Denmark, Switzerland, Germany, Canada, Italy, Japan, Norway, Poland and France. The purpose of this network is to enhance the capability of the pre-existing Greenland seismic infrastructure for detecting, locating and characterizing both tectonic and glacial earthquakes, together with other cryo-seismic phenomena. As glacial earthquake activity has been shown to exhibit seasonal and secular fluctuations likely caused by changes in full-thickness iceberg calving rate (Ekström and others, 2006), by improving the detection of these events the GLISN data can provide powerful monitoring of glaciological processes. All data from GLISN are freely and openly available through various institutes, including the ORFEUS Data Center (ODC) and the Incorporated Research Institutions for Seismology (IRIS). GLISN stations are almost uniformly equipped with Streckeisen STS-2 seismometers (flat response between $120 \mathrm{~s}$ and $50 \mathrm{~Hz}$ ) and Quanterra Q330 digitizers. Except for on-ice and extremely remote stations, data are acquired and distributed in real-time.

The present study uses regional seismic broadband recordings of calving events in northwestern Greenland. We use data from three stations (KULLO, NUUG and ILULI; Fig. 1), which were installed in the summers of 2009 and 2010 near the shoreline in the vicinity of major calving glaciers. Since their installation the instruments have been operating continuously with only minor interruptions. For each of the three stations, this has resulted in a data return above $99 \%$ with only $\sim 20$ data gaps per year.

Associated with this project, offline pressure sensors were temporarily installed in the fjords close to stations ILULI and NUUG. The sensor specifications and operational periods are shown in Table 1. The pressure data effectively measure water level above the sensor. In the event of seiching in the fjord, the water pressure sensors directly measure the amplitude of the seiche at the site, whereas the seismometers respond to ground tilt induced by the changing fjord water heights in the vicinity of the station. Seismometer response to tilt induced by water waves has been documented in a variety of previous cases, including seiche signals induced by ship traffic in the Panama Canal (McNamara and others, 2011) and tsunamis (Okal, 2007). A tilt signal on a seismometer is characterized by significantly larger signals on the horizontal components compared to the vertical (Wielandt and Forbriger, 1999).

\section{STUDY SITES ON GREENLAND'S NORTHWEST COAST}

Installed in the town of Ilulissat in July 2009, the broadband station ILULI is located $\sim 60 \mathrm{~km}$ from the calving front of Jakobshavn Isbræ (Fig. 1), one of Greenland's largest and 


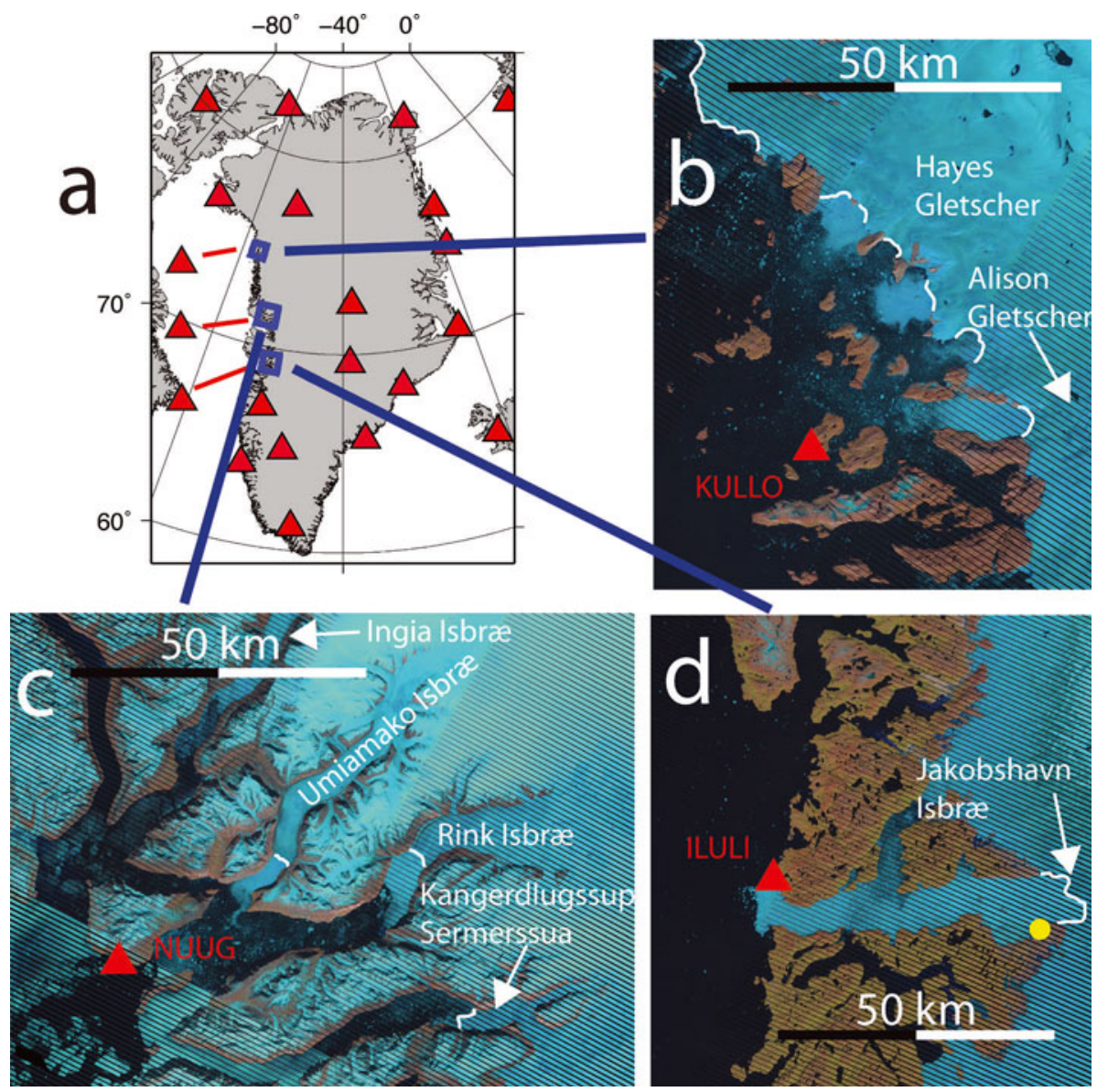

Fig. 1. (a) Overview of GLISN seismic network installed across Greenland. (b-d) Detailed images of the regions near the seismic stations discussed (Landsat images and Landsat mosaic for NUUG region). A water pressure sensor was installed near the shore within $100 \mathrm{~m}$ of NUUG. At ILULI, at different periods, water pressure sensors were installed in llulissat harbor (ILULH, $\sim 3 \mathrm{~km}$ from seismic sensor) and at the mouth of the fjord (ILULS, $\sim 2 \mathrm{~km}$ distant). The location of another pressure sensor, ILULF, near the calving front of Jakobshavn Isbræ, is indicated by yellow dot.

fastest-flowing outlet glaciers draining $\sim 7 \%$ of the entire ice sheet (Bindschadler, 1984). Following $\sim 50$ years of stability (Sohn and others, 1998), the glacier began a rapid retreat in 1998, losing its $15 \mathrm{~km}$ floating tongue (Luckman and Murray, 2005). The retreat was accompanied by thinning rates as high as $15 \mathrm{~m} \mathrm{a}^{-1}$ (Thomas and others, 2003; Krabill and others, 2004), and the flow rate near the terminus accelerated from

Table 1. Operational periods and sampling rates for pressure sensors located in fjords near the seismic sensors. The channel names VDH and LDH conform to the Standard for the Exchange of Earthquake Data (SEED). Note that the numerical labels for ILULS channels refer to two different epochs

\begin{tabular}{lcccc}
\hline Pressure gauge & Start date & End date & $\begin{array}{c}\text { Duration Sampling } \\
\text { rate }\end{array}$ \\
& & & & days \\
& & & & \\
& & & & \\
\hline NUUG LDH & 22 Jul 2010 & 3 Oct 2010 & 73 & 0.333 \\
NUUG VDH & 22 Jul 2010 & 14 Dec 2010 & 145 & 0.033 \\
ILULH LDH & 21 Jul 2010 & 26 Aug 2010 & 36 & 0.200 \\
ILULH VDH & 28 Aug 2010 & 23 Jan 2011 & 148 & 0.033 \\
ILULF VDH & 15 Aug 2009 & 28 Aug 2009 & 13 & 0.033 \\
ILULS LDH 1 & 22 Jul 2010 & 27 Aug 2010 & 36 & 1.000 \\
ILULS LDH 2 & 20 Jul 2011 & 17 Sep 2011 & 59 & 0.200 \\
ILULS VDH & 27 Aug 2010 & 28 Jun 2011 & 305 & 0.033 \\
& & & &
\end{tabular}

$\sim 6000 \mathrm{~m} \mathrm{a}^{-1}$ in 1997 to $12000 \mathrm{~m} \mathrm{a}^{-1}$ in 2003 (Joughin and others, 2004). The glacier has maintained its high velocities, with calving front positions fluctuating seasonally on the order of $6 \mathrm{~km}$ (Joughin and others, 2008b). There exists evidence that the glacier is currently undergoing dynamic changes allowing for iceberg discharge in winter (Cassotto and others, 2010; Fahnestock and others, 2010; Truffer and others, 2010). However, until recently, the glacier formed a small floating tongue in winter as calving typically ceased. This temporary tongue disintegrates in early summer via calving of large tabular icebergs (Amundson and others, 2010), the typical calving style for the previously floating terminus. During the subsequent summer, iceberg discharge occurs mainly via calving of smaller, full-thickness icebergs, which capsize upon detachment (Amundson and others, 2010). Jakobshavn Isbræ is the only major calving front in the vicinity of ILULI and thus the only candidate front for the events we observe at this station. The ice debris cover may not be typical of Greenland's glacierized fjords: in recent years it has been present year-round, although its thickness and integrity change seasonally (Joughin and others, 2008b; Amundson and others, 2010). In contrast, Howat and others (2010) document the clearing of fjord debris cover for glaciers within $300 \mathrm{~km}$ north of Jakobshavn Isbræ. Amundson and others (2012a) demonstrate that calving events at Jakobshavn Isbræ produce seiche signals that are visible on station ILULI (Fig. 1). Up to six glacial earthquakes in a single 
year have been located at this calving front (Veitch and Nettles, 2012).

The broadband station NUUG is located just outside the small fishing community of Nuugaatsiaq in Greenland's Uummannaq district. It was installed in July 2010 near glacier termini located within a system of fjords likely suitable for sustained seiches (Fig. 1). The calving fronts of Ingia and Umiamako Isbræ underwent rapid retreats in 2003, increasing their flow speeds by $20 \%$ and $300 \%$, respectively (Howat and others, 2010). Umiamako Isbræ retreated by $\sim 4 \mathrm{~km}$, constituting the largest retreat in this area (Howat and others, 2010; McFadden and others, 2011). Between 2004 and 2008 it thinned by $\sim 66 \mathrm{~m}$. Concurrently, it underwent acceleration, which may continue into the future (McFadden and others, 2011). Kangerdlugssup Sermerssua has exhibited a stable calving front position although it doubled its speed between 2000 and 2005 and thinned by nearly $60 \mathrm{~m}$ in recent years (Howat and others, 2010; McFadden and others, 2011). During the same period, Rink Isbræ showed little change in terminus position and flow speed (Howat and others, 2010; Joughin and others, 2010). Around the turn of the century, the discharge of Rink Isbræ was five times as large as Kangerdlugssup Sermerssua and about half as large as Jakobshavn Isbræ (Rignot and Kanagaratnam, 2006). It is therefore likely the dominant producer of icebergs in the Uummannaq district. This is also in agreement with glacial earthquake studies, which ascribe all detected events in this region $\left(0-2 \mathrm{a}^{-1}\right)$ to Rink Isbræ (Tsai and Ekström, 2007; Nettles and Ekström, 2010; Veitch and Nettles, 2012).

Near the broadband station KULLO, located at the village of Kullorsuaq since July 2009, the Greenland ice sheet drains through large ice streams and wide calving margins (Fig. 1). The ice streams calve directly into the open ocean, with buttressing rock outcrops forming only few water-filled fjords. Compared to the region near NUUG this suggests fewer water basins suited for seiches. Ice-sheet changes have been moderate over the past decade (Rignot and Kanagaratnam, 2006), except for Alison Gletscher $(\sim 30 \mathrm{~km}$ from KULLO), which from around 2002 began an $8.7 \mathrm{~km}$ retreat and doubled the peak speeds (Moon and Joughin, 2008; Joughin and others, 2010; Howat and Eddy, 2011; McFadden and others, 2011). The glacier's terminus and speed stabilized relatively quickly around 2007, arguably because of steep slopes reaching far inland (McFadden and others, 2011). As expected for a rapid retreat, Alison Gletscher has produced up to four glacial earthquakes a year between 2003 and 2008 (Veitch and Nettles, 2012). In contrast, Hayes Glacier ( $40 \mathrm{~km}$ from KULLO) experienced a minor slowdown between the early and mid-2000s with approximately constant mass balance (Rignot and Kanagaratnam, 2006). Since 2006, it has only produced one glacial earthquake (Veitch and Nettles, 2012).

\section{EVENT CHARACTERIZATION}

Broadband calving seismograms recorded nearshore within $100 \mathrm{~km}$ of the source are characterized by a rich and distinctive wave train. Figure 2 demonstrates the different character of typically observed signals recorded on the north-south component at station NUUG. The records include a calving event from 23 August 2010. For this event, as well as for many calving events we have analysed, the north-south component most clearly exhibits the typical features of a calving seismogram as discussed below.
Satellite images from the nearby glaciers taken before and after this date confirm the contemporaneous occurrence of iceberg calving and are discussed later. The general character of the calving seismogram in Figure 2 is also representative of other calving events at the seismic broadband stations ILULI, NUUG and KULLO. Figure 2 also includes signals from a large teleseism (M7.6 Kermadec Islands, 6 July 2011), a regional earthquake (M3.2, epicentre $\sim 120 \mathrm{~km}$ northwest of station ILULI, $\sim 200 \mathrm{~km}$ away from NUUG) and a sample of seismic noise.

In Figure 2a, all the records are shown without any processing or filtering. The calving event is characterized by a high-frequency onset followed by a nearly monochromatic long-period energy that resonates for many hours that is absent from all other signal types. Figure $2 \mathrm{~b}$ shows the same data, after integration and bandpass-filtering between 0.001 and $0.01 \mathrm{~Hz}$. Additionally, data recorded on the nearly co-located water pressure gauge are plotted. Though large teleseisms also excite energy with similar amplitude in this frequency band, the duration is short compared to the several hours of resonance seen during the calving. As the frequency, phase, envelope amplitude and duration of the calving seismogram closely match the water pressure data, it is clear that the seismometer is responding to the seiche measured with the pressure gauge.

In Figure 2c, all the seismic data are presented using a bandpass filter that accentuates large-amplitude surface waves at low frequencies $(0.02-0.05 \mathrm{~Hz})$. All signals use the same scale, except the teleseism, which is scaled down by a factor of 250. Though the calving event does generate lowfrequency surface waves (in this case, two distinct peaks separated by $20 \mathrm{~min}$ which may be indicative of the detachment of several icebergs as documented by Walter and others, 2012), the amplitudes do not exceed the background noise by more than a factor of 5 . In Figure $2 d$, the waveforms are bandpass-filtered between 1 and $3 \mathrm{~Hz}$ to highlight the high-frequency components of the signal. All the signals are on the same scale. The teleseism is at such great distance that the high-frequency signal is barely perceptible, with similar amplitude to the noise. The calving event produces clear energy only during the second of the clear low-frequency surface wave energy transients. During calving, high-frequency energy is generated during iceberg detachment ( $\mathrm{O}^{\prime}$ Neel and others, 2007) and water surface impact (Bartholomaus and others, 2012), as well as motion of ice debris in the fjord, and typically lasts several minutes (Amundson and others, 2008; Walter and others, 2012). The high-frequency calving seismicity typically precedes the seiche signal by some tens of minutes (Amundson and others, 2012a). It tends to be emergent, and cultural noise can often generate a stronger signal.

The coincidence of the surface wave arrival (Fig. 2c) with a high-frequency seismicity burst is in agreement with the conceptual model that glacial earthquakes are generated by contact forces between a detaching iceberg and an obstacle coupled to the solid Earth, such as the fjord bottom or glacier terminus (e.g. Amundson and others, 2008, 2012a; Tsai and others, 2008; Walter and others, 2012). However, there also exist examples when seismic surface wave generation and high-frequency fracture seismicity do not clearly coincide (Walter and others, 2012). For the example shown in Figure 2 this is the case for the first surface wave arrival. This may indicate that during a multiple-iceberg calving event, some icebergs detach and capsize more 'freely' with 


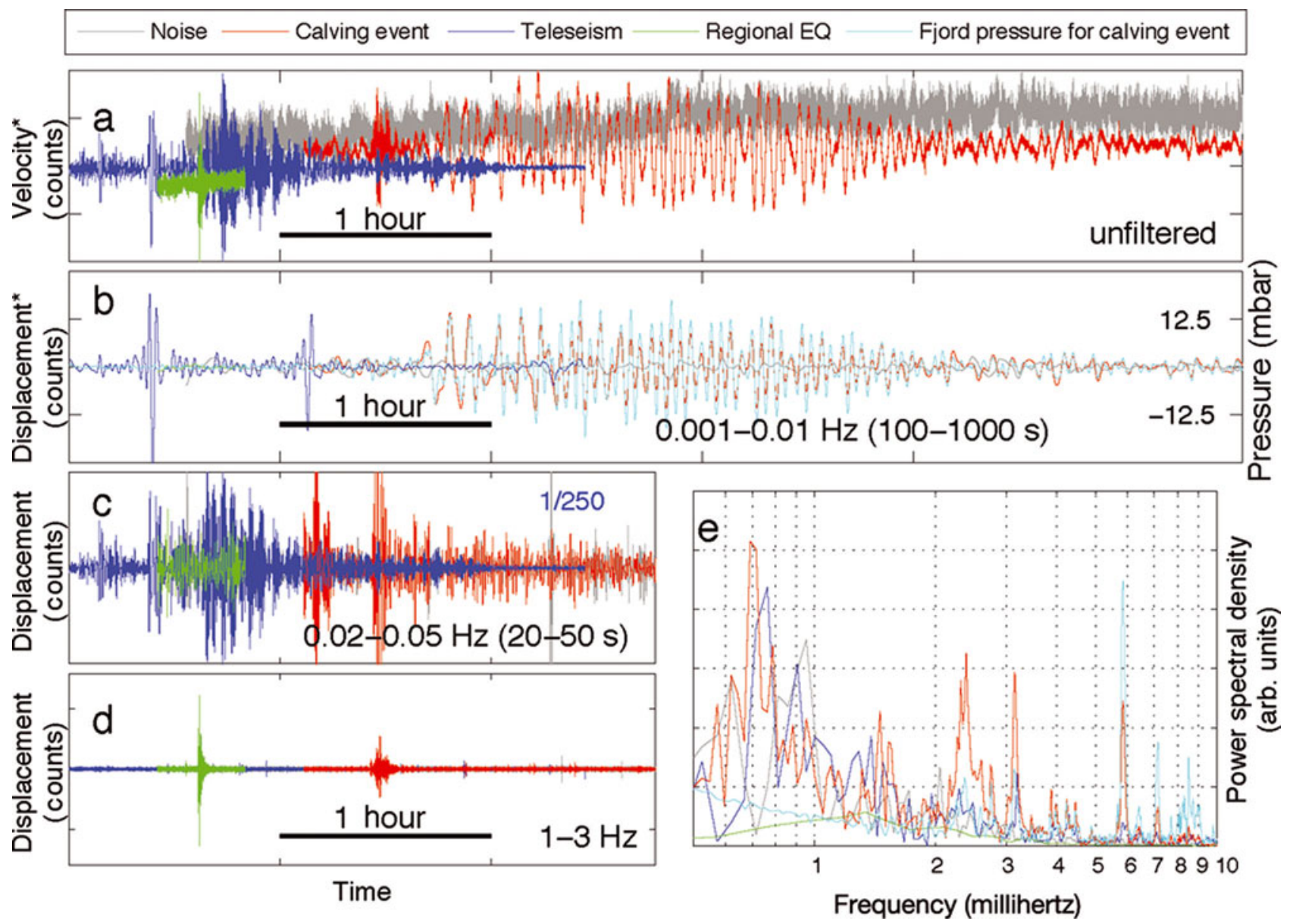

Fig. 2. Comparison of different signals recorded on the north-south component at NUUG. Records are presented from seismic background noise, a local calving event (23 August 2010), a teleseismic event $\left(M_{w}=7.6\right.$; Kermadec Islands, 6 July 2011) and a regional earthquake $\left(M_{w}=3.2\right.$ on 20 August 2010 at 20:53 UTC, $\sim 120 \mathrm{~km}$ northwest of ILULI, $200 \mathrm{~km}$ south of NUUG; Fig. 1). (a-d) share the same scale on the $x$-axis (note that the scale bar in (c) is omitted for clarity). Seismograms have not been corrected for instrument response. Note that in (b-d) the time series shown in (a) (raw data) is integrated. The low-frequency corner of the flat response of the STS-2 sensor is $0.0083 \mathrm{~Hz}(120 \mathrm{~s})$, hence the time series in (c) and (d) are proportional to displacement. The vertical axes of (a) and (b) are labelled 'Velocity*' and 'Displacement*' respectively, because the signals include frequencies outside the sensor's flat response. (e) The respective low-frequency velocity spectra. For the same calving event, pressure data from the NUUG fjord hydrograph (location shown in Fig. 1) are plotted in (b) and (e). Each seismogram in (a) is normalized to its maximum. For (c), the blue number indicates that the scale of the teleseism seismogram was reduced by a factor of 250 with respect to the other seismograms.

relatively little englacial fracturing or displacement of fjord debris cover.

In Figure 2e, the long-period components of the signals are displayed in the frequency domain. The calving event is characterized by a number of narrow and distinct spectral peaks. The pressure gauge data also share several of these peaks, in particular the dominant resonance near $0.006 \mathrm{~Hz}$. None of the other event types excite significant energy near this frequency. The seismic spectrum contains various additional low-frequency peaks, which are only weakly present in the fjord pressure data. This may be due to the nature of the sensor installation: near NUUG, the fjord system is complex (Fig. 1). Depending on the specific glacier terminus, any single calving event may induce seiching with different resonating frequencies in nearby basin systems. Whereas the water pressure sensor is only sensitive to resonances in the local fjord, the seismic sensor can respond to seiching-induced tilts that occur in nearby basins with different resonance periods.

Figure 2 demonstrates why we focus on identification of calving events using long-period energy $(<0.01 \mathrm{~Hz})$ associated with seiching. Regional and teleseismic earthquakes and even seismic background noise can generate energy in all three frequency bands shown in Figure 2. However, the $0.001-0.01 \mathrm{~Hz}$ range is least contaminated by other signals, which include very low-frequency surface waves from relatively rare major teleseismic events, local tilting from wind or cultural noise, and instrument glitches such as mass re-centrings. Cultural noise and electronic instrument glitches, in particular, can produce false alarms for our automatic calving seiche detector at station KULLO, as discussed below. Nevertheless, these sources have a far shorter duration than seiche signals. Furthermore, in this frequency band, teleseismic events can be clearly distinguished from seiches by comparison between vertical and horizontal amplitudes: teleseisms have similar amplitudes between these components, but in the case of calving seiches the sensor responds to minor tilts. In this case the vertical component has order-of-magnitude smaller amplitudes than the horizontal components (Clinton, 2004; Pino, 2012). Accordingly, the seiche seismogram in Figure 2 has a horizontal-to-vertical (H/V) ratio of 20 (using the northsouth component). In contrast, the teleseismic surface waves typically have an $\mathrm{H} / \mathrm{V}$ ratio of $\sim 1$. 
Table 2. Individual station parameters for automatic seiche detection. Columns $2-4$ define the initial detection phase: high-pass (HP) and low-pass (LP) corners of the four-pole bandpass filter; lengths used to define the short-term (STA) and long-term (LTA) averages for the trigger; threshold of STA/LTA algorithm to initiate and terminate detection, indicating event duration. Columns 5-7 describe the parameters used in the secondary event filtering: minimum event duration; frequency bands for determining station-dependent characteristic amplitude; minimum ratio of the average horizontal to vertical components within the bandpass

\begin{tabular}{lcccccc}
\hline & Bandpass HP/LP & STA/LTA & $\begin{array}{c}\text { STA/LTA } \\
\text { threshold on/off }\end{array}$ & Min duration & Characteristic frequencies & Min H/V ratio \\
& $\mathrm{Hz}$ & $\mathrm{S}$ & & $\mathrm{S}$ & $\mathrm{Hz}$ \\
\hline ILULI & $0.0012 / 0.007$ & $500 / 3500$ & $2.3 / 1.7$ & 1200 & $0.0012-0.002 ; 0.002-0.004$ & 7 \\
KULLO & $0.0015 / 0.007$ & $500 / 3500$ & $2.3 / 1.7$ & 900 & $0.005-0.007 ; 0.007-0.009 ; 0.0015-0.002$ & 7 \\
NUUG & $0.0015 / 0.007$ & $500 / 3500$ & $2.3 / 1.7$ & 1400 & $0.002-0.0025 ; 0.0027-0.0032 ; 0.004-0.0045$ & 7 \\
\hline
\end{tabular}

Although calving events generate seismic signals in each frequency band, the seiche signal consistently has the best signal-to-noise ratio. Indeed, during some seiche detections, surface wave and/or the high-frequency energy does not emerge above the noise even at distances of less than $100 \mathrm{~km}$. Furthermore, these higher-frequency bands are rich in frequently occurring transient signals produced by cultural noise and, in particular, earthquake sources. The 0.001$0.01 \mathrm{~Hz}$ passband is therefore suitable for automatic detection of iceberg calving events using the seiche approach.

\section{SEICHE DETECTION}

Our strategy for the automated detection of calving events is to target the seiche signals. In order to identify all transient energy signals at long periods, we apply a simple triggering detector to the bandpassed continuous waveforms. In order to maximize the completeness of this first-stage catalogue we use a conservative parameter set for the triggering algorithm. The detector was first tuned using known calving events from first-hand observations at Jakobshavn Isbræ (personal communication from M. Lüthi, 2011) and the glacial earthquake catalogue (most recent update from Veitch and Nettles, 2012). Our conservative parameter choice also produces a significant number of false detections. We present an automated approach to solving this problem, and a second solution which requires user interaction. For the latter we manually review all STA/LTA (short-term average/long-term average) detections. This is the most reliable, although tedious, solution for removing the false detections from the automatic algorithm. For the automated approach, we propose a second stage that filters the initial catalogue, only including events in the final automatic catalogue that exhibit certain characteristics expected of seiches. The first check in this second stage discriminates seiching from other signals by setting a threshold for signal duration. This removes brief transients and all but the largest teleseisms. A further check that removes teleseismic signals requires the calving events to have a minimum ratio between the peak amplitudes of the horizontal and vertical components. A final check that removes spurious noise, or indeed small calving events that are difficult to verify, requires events to reach a minimum amplitude for the characteristic spectral peaks. As calving events from different sources exhibit quite different characteristics - in particular, the seiche frequencies and durations vary according to the fjord geometry - the actual threshold parameters are station-dependent (Table 2).

\subsection{Detection algorithm}

We implement the first stage of the calving seiche detector by applying an STA/LTA (Allen, 1978) algorithm to bandpassfiltered raw data streams (Table 2). Although the seiche signal has largest amplitudes on the horizontal components, this detection is performed on the vertical, as it has substantially less long-period noise and hence the highest signal-to-noise ratio (see Section 7.3). A preliminary detection is made when the STA/LTA envelope amplitude exceeds 2.3. In the second stage we only retain events where the STA/LTA trigger threshold is maintained for a station-specific time-span (Table 2). In the final stage, only events whose spectral amplitudes exceed a station-specific value and which exhibit an $\mathrm{H} / \mathrm{V}$ ratio of $<7$ are kept. At least one of the horizontal components has to pass the H/V criterion. These thresholds used for the frequency bands, event durations and spectral amplitude were selected using a trial-and-error approach to ensure detection of a manually selected set of calving seiche signals: Inspecting the available continuous seismic record we made sure that our algorithm triggers on signals similar to those of known calving events (personal communication from M. Lüthi, 2011; Veitch and Nettles, 2012). This STA/LTA detection algorithm is implemented on Seiscomp3 (Hanka and others, 2010; http://www.nathazards-earth-syst-sci.net/10/2611/2010/nhess-10-26112010.html), and subsequent analyses of the preliminary detections are performed using Seismic Analysis Code (SAC; Goldstein and others, 2003).

\subsection{Detection verification}

Visual calving event confirmation with first-hand observations (e.g. O'Neel and others, 2007; Köhler and others, 2011) or time-lapse photography (Amundson and others, 2008, 2012a; Walter and others, 2012) is unrealistic for the 250 detected calving events, which occurred over $>2$ years in extremely remote terrain. Instead, when possible, we verified our detections with water pressure data in nearby fjords. However, the pressure sensors were only installed near ILULI and NUUG (Table 1), and even for these data there are extended periods without measurements. Furthermore, a potential problem with pressure gauge data is that occasionally they may record seiches caused by mechanisms other than calving, such as freely rotating icebergs, landslides or weather-related events.

Satellite images are an alternative to direct observations. They can be used to verify that our automatic seiche detections correspond to iceberg calving events. However, the spatial resolution of satellite images is limited. In 


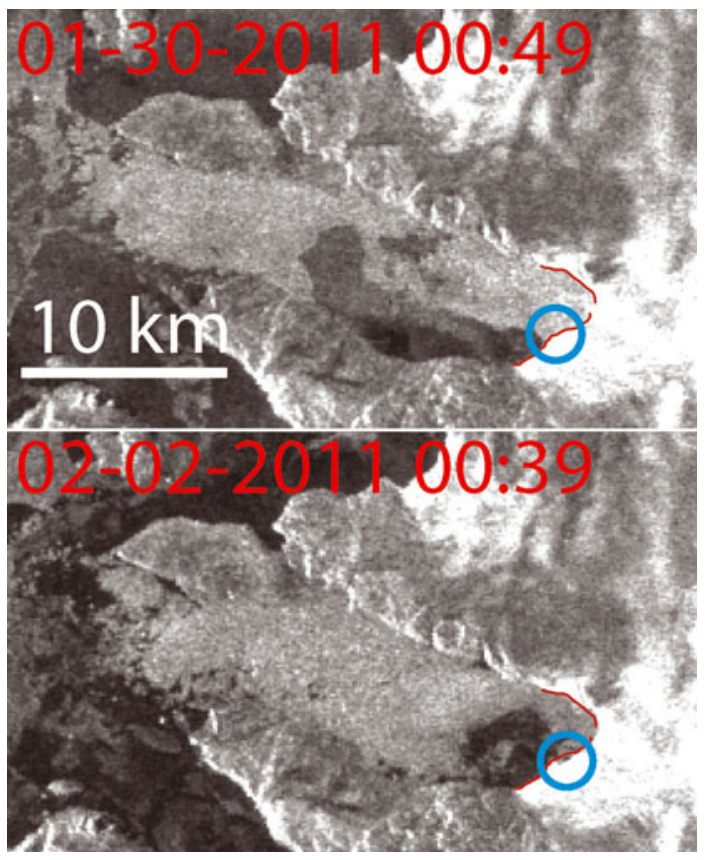

Fig. 3. Envisat ASAR image pair from terminus of Alison Gletscher taken about 11 hours before (top) and 2.5 days after (bottom) calving detection at KULLO on 30 January 2011 at 10:53. The red line traces the pre-calving terminus and highlights the calved area in the bottom image (blue circle). In addition to the chunk missing from the terminus, there is a major change in ice melange near the terminus.

addition, cloud-free image pairs are rarely taken immediately before and after a calving event, so the temporal resolution of satellite-based calving event detection cannot compete with seismic methods. In this study, we use an image library provided daily by the Danish Meteorological Institute (http://ocean.dmi.dk/arctic/modis.uk.php). It contains data from the Envisat satellite and its Advanced Synthetic Aperture Radar (ASAR), C European Space Agency. The images have sufficient resolution $(\sim 150 \mathrm{~m})$ to identify major calving episodes and are generally available at intervals of tens of days or less. A systematic effort to create an independent calving catalogue for each calving front by using satellite images to monitor changes in terminus geometry could be used to estimate the completeness of our calving catalogue. Though this is beyond the scope of the present study, we demonstrate the potential of satellite images for calving event confirmation in Figures 3 and 4. The shown events at KULLO and NUUG do correspond to coeval mass wastage at a calving front.

Figure 3 shows ASAR images of Alison Gletscher's terminus near KULLO taken on 30 January 2011 and 2 February 2011 (see also Fig. 1). A seiche was detected within this time window at KULLO on 30 January 2011 at 10:53. The second image presented clearly shows a missing piece in the terminus due to one or more calving events. The image pair furthermore highlights a change in the proglacial melange cover, which may be due to upwelling of fresh water from subglacial discharge (e.g. Motyka and others, 2003; Rignot and others, 2010) or local winds.

There exist ASAR images taken $\sim 5$ days before and 1.5 days after the calving seiche detection at NUUG on 23 August 2010 at 03:20 (Figs 2 and 4). On these images it is more difficult to trace the terminus positions and to
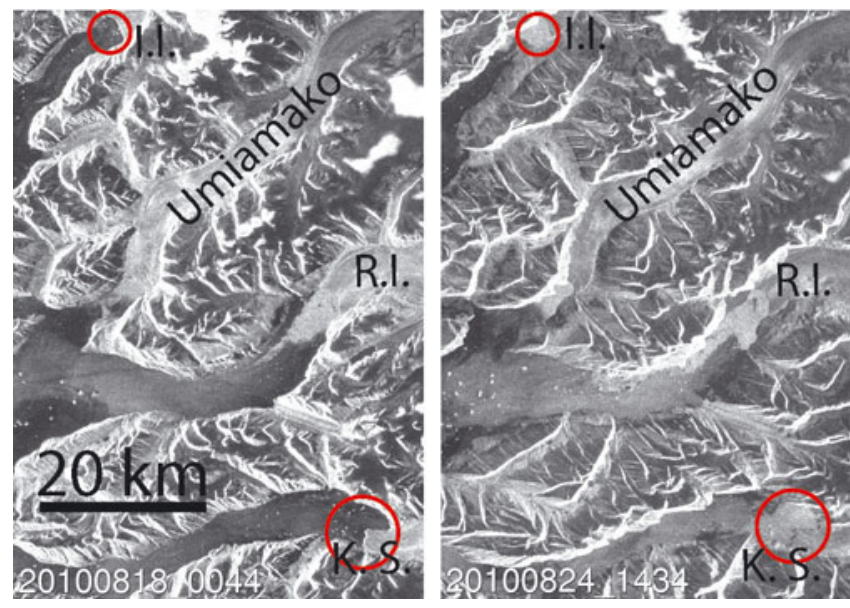

Fig. 4. Envisat ASAR image pair of the NUUG region (Uummannaq district), taken about 5 days before (left) and 1.5 days after (right) the seiche detection on 23 August 2010 at 03:20 (Fig. 2). The pre- and post-calving termini are difficult to trace in these images (due to lighting and the presence of melange cover); however, the appearance and changes of the proglacial melange (red circles), in particular at Ingia Isbræ (I.I.) and Kangerdlugssup Sermerssua (K.S.), suggest calving events likely happened in between the images. R.I. refers to Rink Isbræ (shown in Fig. 1).

detect changes in terminus geometry. There are changes in proglacial melange cover at all shown calving fronts. However, as these changes may be due to changes in fjord currents or wind patterns they carry little significance. On the other hand, we note the appearance of severalkilometre-long debris covers in the fjords of Ingia Isbræ (I.I.) and Kangerdlugssup Sermerssua (K.S.), which suggests that substantial calving occurred around the detection time.

\subsection{Detection statistics}

Figure 5 illustrates the statistics of our automatic detection time series with events binned in 1 month intervals. The figure also shows the result of the visual review of all initial STA/LTA detections, i.e. all automatic detections as well as those rejected by the thresholds for amplitude and $\mathrm{H} / \mathrm{V}$ ratio. Moreover, where possible, we visually confirmed that the seiche signal was present in the fjord pressure sensor data. This manually reviewed catalogue best represents the calving activity derived from our seiche detections. The manual calving catalogues for each station are included in Table 3 in the Appendix. Significant additional confidence in the manual catalogue was gained by visual inspection of the entire 2 year continuous seismic archive subjected to a bandpass filter between 200 and 1000 s. We note that missed events can occur due to gaps in data, which also produces a blind period for the detector, corresponding to the duration of the long-term average window. However, this occurs rarely, as the data return of all three stations exceeds $99 \%$. Furthermore, data gap occurrence is not influenced by the seasons and thus cannot mimic or mask seasonal fluctuations in seiche detection.

Figure 5 shows that the automatic catalogue can miss up to six events per month. Furthermore, it can include an even greater number of false triggers. The problem of false detections is particularly severe for KULLO, which has $>50$ monthly false detections in summer 2011. In total, 79\% of all KULLO detections were false, while the automatic detector incorrectly rejected $18 \%$ of the manually confirmed 


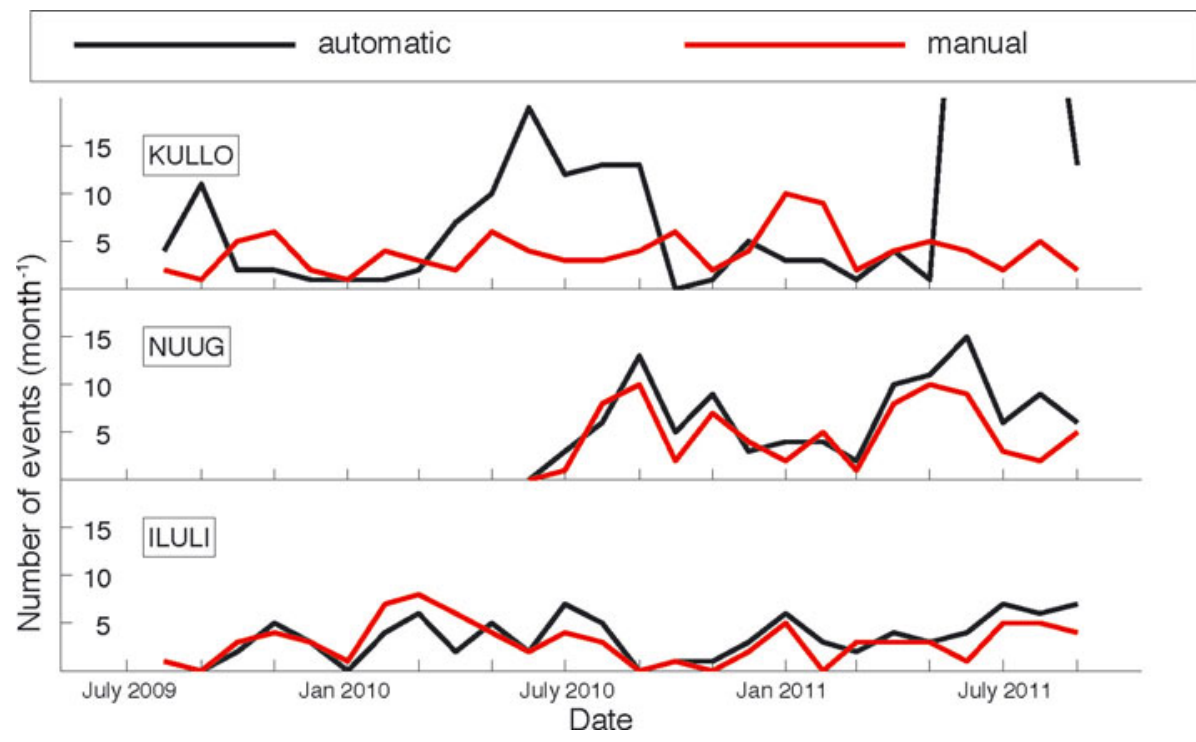

Fig. 5. Automatic (black) and manual (red) detections per month at the three seismic stations. Note that in contrast to KULLO and ILULI, the NUUG detection time series shows a seasonal fluctuation. During some months in 2011, the number of automatic detections at KULLO exceeds 50 and thus the limits of the vertical axis.

events. Visual inspection of the continuous waveforms shows that station KULLO generates a large amount of long-duration long-period noise, which falsely triggers our detection algorithm. Similar to data gaps (also more frequent in the KULLO record), such noise can decrease the trigger sensitivity for several hours, potentially leading to missed calving detections. We believe this noise occurs because, though the sensor is located on rock, it is underneath an occupied house near one of the four foundation piers. It may thus be susceptible to local tilting induced by transient forces on the foundation due to wind or house use.

In an attempt to reduce the high rate of false detections at KULLO, we varied the amplitude and duration cut-off values (Table 2), but were not able to significantly improve performance. On the other hand, the performance of the automatic detector at ILULI and NUUG is more reliable, with $17 \%$ and $6 \%$ of the manual detections missed respectively. Conversely, $29 \%$ and $33 \%$ of the automatic detections for the respective stations were false.

\section{COMPARISON WITH OTHER CATALOGUES}

To further evaluate the performance of our calving detector we compare our automatic and manual catalogues with existing iceberg calving catalogues based on glacial earthquake detection (Veitch and Nettles, 2012) and a calving catalogue derived from a combination of seismic and visual observations (Amundson and others, 2012a). It should be stressed that these catalogues all use different datasets and use different frequency bands of calving seismograms. Consequently, the detection techniques may well be sensitive to different styles and sizes of calving events. Therefore, the ideal catalogue would most likely be a combination of the existing catalogues and our manual seiche detection record.

We focus on the detections of Veitch and Nettles (2012) in our three candidate regions. This catalogue spans the years 2006-10 and thus builds on earlier glacial earthquake catalogues of Tsai and Ekström (2007). For the particular case of calving events from Jakobshavn Isbræ, our catalogues are compared with the updated version (personal communication from J.M. Amundson, 2012) of the Amundson and others (2012a) catalogue. Whereas the Veitch and Nettles (2012) catalogue also served as a guideline for the choice of our detection parameters, the updated version of Amundson and others (2012a) was not used in the development of our trigger algorithm. The Amundson catalogue documents the calving history of Jakobshavn Isbræ between 1996 and 2011 and is based on a manual analysis of local high-frequency seismicity, satellite imagery and, when possible, time-lapse footage of Jakobshavn Isbræ's terminus. For Jakobshavn Isbræ, this is presently the most complete record of calving events. Requiring low-frequency surface wave energy recorded at global distances, the trigger algorithm of Veitch and Nettles (2012) targets relatively large calving events only. However, it can potentially detect calving events at all major outlet glaciers of Greenland.

Our automatic seiche detections include all but one of the ten glacial earthquake events (nine detections at Jakobshavn Isbræ and one detection at Rink Isbræ) detected by Veitch and Nettles (2012). Our automatic and manual catalogues at ILULI are compared with the updated catalogue of Amundson and others (2012a) in Figure 6. Figure 6a compares their catalogue with our automatic catalogue. The number of events occurring each month detected by either catalogue varies between 0 and 10 . During most months, there exist events that are detected by both catalogues, as well as events that are detected only by one of the two methods. When we consider our manual catalogue (Fig. 6b), the number of events only present in our seiche catalogue decreases slightly while the number of events observed by both methods increases. This confirms (1) our manual catalogue, based on a visual inspection of all STA/LTA triggers, correctly eliminates a number of false calving events in the automatic catalogue; and (2) in a small number of cases, a few events that match the STA/LTA trigger criterion but are subsequently rejected are likely true events as they also appear in the updated catalogue of Amundson and others (2012a). On the other hand, 30 calving events (the summation of green bars in Fig. 6b) in the updated 

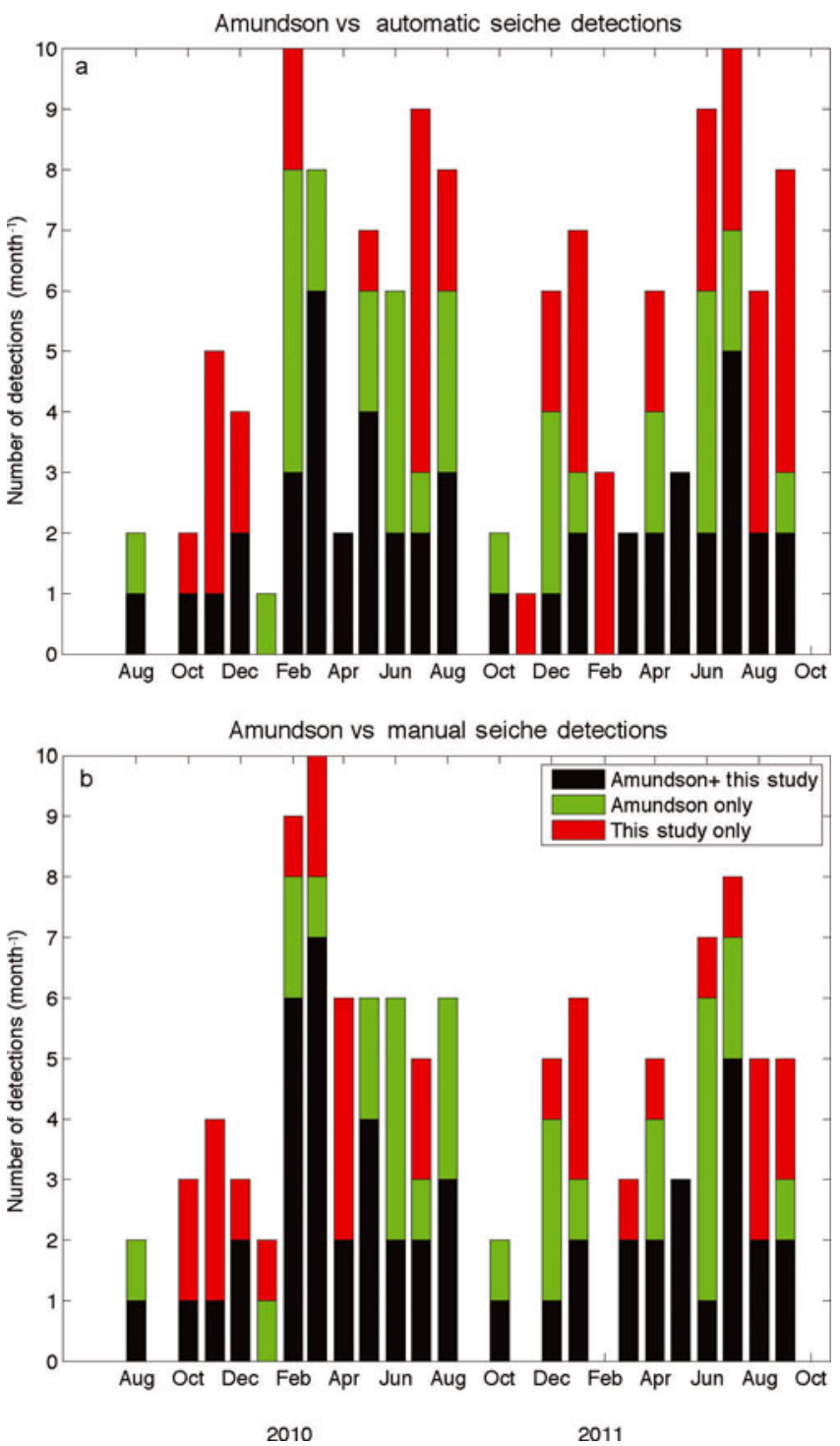

Fig. 6. Comparison between monthly detection in the automatic (a) and manual (b) catalogues ('seiche') and the updated catalogue by Amundson and others (2012). Note that this comparison is limited to calving events at Jakobshavn Isbræ detected at station ILULI.

catalogue of Amundson and others (2012a) do not trigger the STA/LTA algorithm. The reason is most likely that these calving events do not produce a seiche strong enough to be detected by our seismic sensor at ILULI.

The majority of events in the manual catalogue are also in the updated catalogue of Amundson and others (2012a). Combining both catalogues, there are on average four to five events at Jakobshavn Isbræ per month. Nevertheless, there are events (represented by red bars) which produce seiches but which are not included in the updated version of Amundson and others (2012a). These are less straightforward to interpret. One reason may be that events in the Amundson catalogue are required to have observable highfrequency seismic energy and they have to be visible in satellite and/or time-lapse images. Furthermore, Amundson and others (2012a) only consider calving events, which produce multiple icebergs as indicated by more than one burst in high-frequency seismicity. Consequently, the seiche catalogue may in fact identify previously unknown calving events that may be too small to be visually identified or emit significant high-frequency energy. At the same time we cannot exclude the possibility that at least occasionally our trigger algorithm may also detect seiches which are unrelated to calving events (e.g. freely capsizing icebergs, strong wind or landslides).

\section{DISCUSSION}

\subsection{Seasonality in calving activity}

Figure 5 shows that for NUUG and KULLO the maximum monthly number of manually confirmed detections exceeds ten. Fewer events are detected at ILULI. The reason could be that the catalogue from ILULI includes only calving events from Jakobshavn Isbræ (Amundson and others, 2012a), whereas calving from several nearby glaciers may trigger detections at NUUG and KULLO (Fig. 1). However, it is also possible that calving at Jakobshavn Isbræ is characterized by few, large events.

The stations have only been operational since summer 2009 for KULLO and ILULI, and summer 2010 for NUUG. Hence our catalogue only spans two full years for two stations, and a single year for NUUG. Nevertheless, our catalogue (Fig. 5) suggests that for all three regions there is no seasonal period during which calving ceases altogether. Specifically, for ILULI, over the period of operation, there are only four months without any manually detected event. Even during winter we typically observe several events each month. Previous studies have indicated that calving ceased completely, at least during some winters, following the retreat of Jakobshavn Isbræ, which began in the early 1990s (Amundson and others, 2010, 2012a). Indeed, up to summer 2010 the glacial earthquake catalogue from Veitch and Nettles (2012) showed a clear seasonal oscillation, with most events detected in June-July and no events detected in September-January. Thus, our recent seiche detections during winter months may at least partially be explained by iceberg discharge at Jakobshavn Isbræ. This is in line with the findings of Podrasky and others (2012) that the glacier underwent only a minor advance during winter 2009/10. Accordingly, the recent glacial earthquake detection time series also shows detections at Jakobshavn Isbræ which occur extraordinarily early in 2010 (Veitch and Nettles, 2012). In addition, recent satellite observations have also suggested such an initiation of winter calving. A possible explanation is that currently warming fjord waters reduce the melange's ability to exert a back-stress on the terminus during winter (Cassotto and others, 2010; Fahnestock and others, 2010; Truffer and others, 2010).

Although the detection time series from NUUG (Fig. 5) is the shortest, it appears to exhibit seasonal fluctuations in calving activity, unlike the other stations. The glaciers near NUUG all show a seasonal presence of melange that begins to form in January and February and tends to clear out in June. Due to the resulting changes in buttressing effect of the melange, this cycle correlates well with terminus advances and retreats (Howat and others, 2010). We suggest such seasonality in calving front dynamics is also responsible for the seasonal fluctuations in calving seiche detections at NUUG (Fig. 5).

Similar to ILULI, the detection time series at KULLO shows little or no seasonality. However, in view of the large number of false detections, one has to be careful not to overinterpret this observation. We tentatively suggest that a lack of seasonality in calving activity may be due to the absence of buttressing from proglacial melange. Figure 1 does 


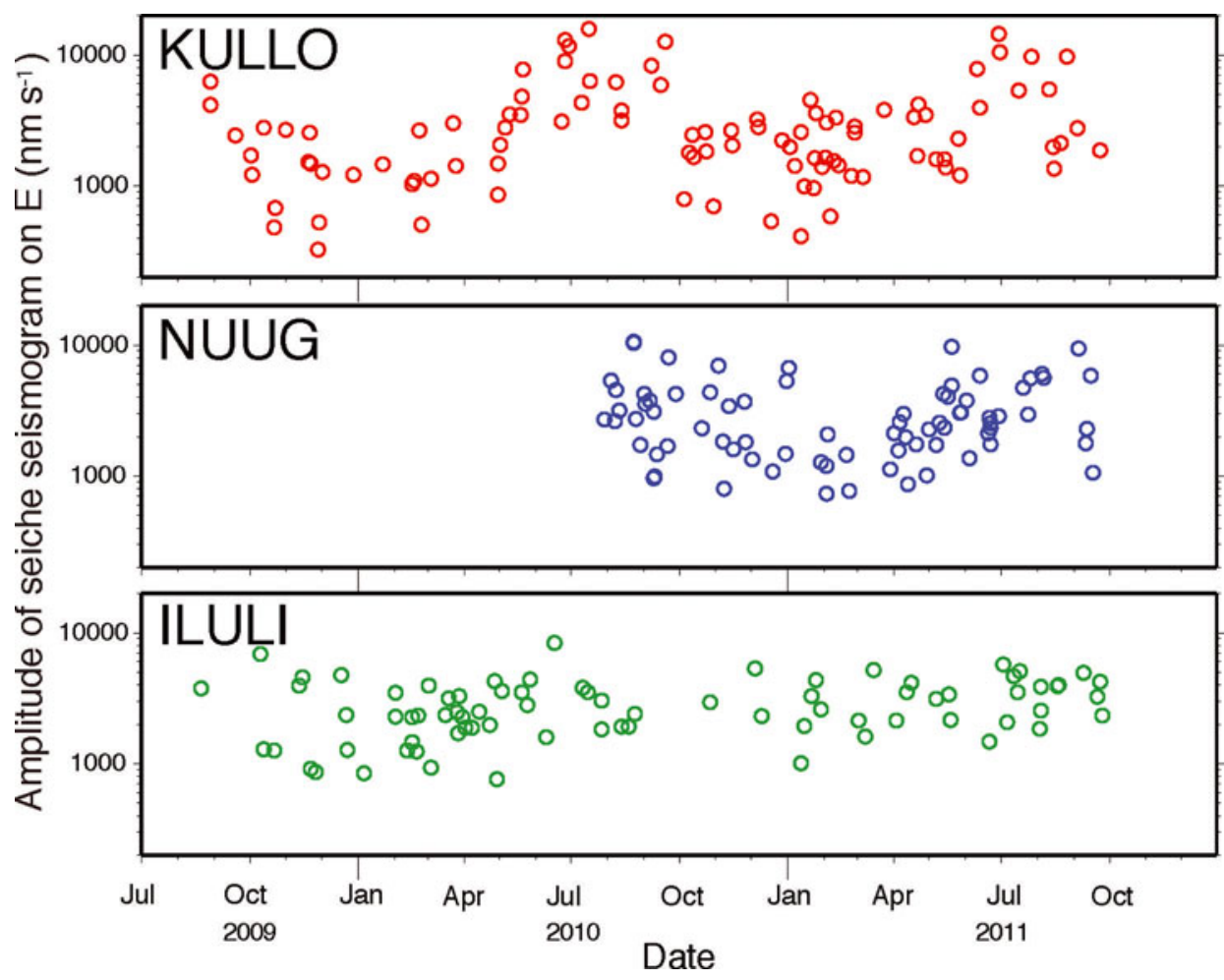

Fig. 7. Maximum amplitudes on east (E)-component seiche seismograms for all calving events in the manual catalogue (see Table 2 for bandpass used for each station). Note that the seiche signals at KULLO and NUUG exhibit a clear seasonal fluctuation, with relatively strong amplitudes in late summer and early autumn.

indicate that ice debris accumulates in front of glacier termini near KULLO. However, compared to the NUUG and ILULI regions, fewer elongated fjords exist near KULLO. As a result, there may not be sufficient confinement for proglacial melange in order to significantly influence ice discharge.

\subsection{Changes in signal characteristics}

The recordings at NUUG and KULLO show seasonal changes of seiche amplitudes (calculated as maximum amplitude recorded on any component during the seiche). This is most clearly seen on the east-west component shown in Figure 7. At NUUG and KULLO, seiche amplitudes tend to be highest during late summer. Such an amplitude variation over time and season cannot be observed in the corresponding low-frequency surface wave frequency band on the same component (Fig. 8).

At periods between 0.1 and $1 \mathrm{~Hz}$, sea ice can substantially dampen ocean gravity waves in Arctic and Antarctic waters (Grob and others, 2011; Tsai and McNamara, 2011). However, recent observations (Bromirski and Stephen, 2012) of ice-shelf response to infra-gravity waves only document a minor damping effect of sea-ice cover at lower frequencies $(0.004-0.02 \mathrm{~Hz})$. The seiche signals observed at KULLO, NUUG and ILULI contain energy between 0.001 and $0.01 \mathrm{~Hz}$, which suggests that the observed seasonality in seiche amplitudes cannot be fully attributed to damping effects of sea ice. Instead, we suggest that seasonal changes in seiche amplitudes are the effect of changes in melange and sea-ice cover on the generation rather than the transmission of calving seiches. Laboratory studies (Amundson and others, 2012b; Burton and others, 2012) as well as theoretical (Tsai and others, 2008; Amundson and others, 2010) and observational studies (Walter and others, 2012) suggest that melange cover in the fjord affects not only the detachment but also the capsizing of icebergs by adding drag forces during the rotation. Accordingly, less rotational energy may be converted into standing fjord waves when a thick sea-ice or melange cover is present, resulting in lower seiche amplitudes.

The frequency content of seiche signals also exhibits considerable temporal variation, which is particularly pronounced on the north-south components of NUUG (Fig. 9). Here a strong spectral peak at $0.006 \mathrm{~Hz}$ is particularly interesting, as it is absent during the earlier months of 2011 and immediately following the station installation. There are several potential explanations for changing boundary conditions, which may give rise to the observed variation in spectral character. First, individual spectral peaks may be characteristic for a particular fjord basin (e.g. Lee, 1971). However, this cannot explain spectral changes of records at ILULI, which we have argued is only sensitive to calving events from Jakobshavn Isbræ. Furthermore, this line of reasoning would imply that, near NUUG, different glaciers calve during different times of the year, which seems unlikely for neighbouring glaciers. An alternative explanation could be seasonal fluctuations in terminus positions. Although terminus positions currently vary $<1 \mathrm{~km}$ in the NUUG region (Howat and others, 2010), these fluctuations may be enough to subtly but measurably alter the resonance frequencies of fjord water bodies. Finally, our preferred explanation for changing seiche spectra is the variation in proglacial ice melange cover combined with the seasonal presence of sea ice. This is supported by recent numerical calculations (MacAyeal and others, 2012) showing that the presence of closely spaced icebergs within a fjord introduces 'band gaps' in normal oscillations of proglacial fjords. In addition, such closely spaced icebergs can lengthen the periods of certain seiche modes by $>400 \%$. 


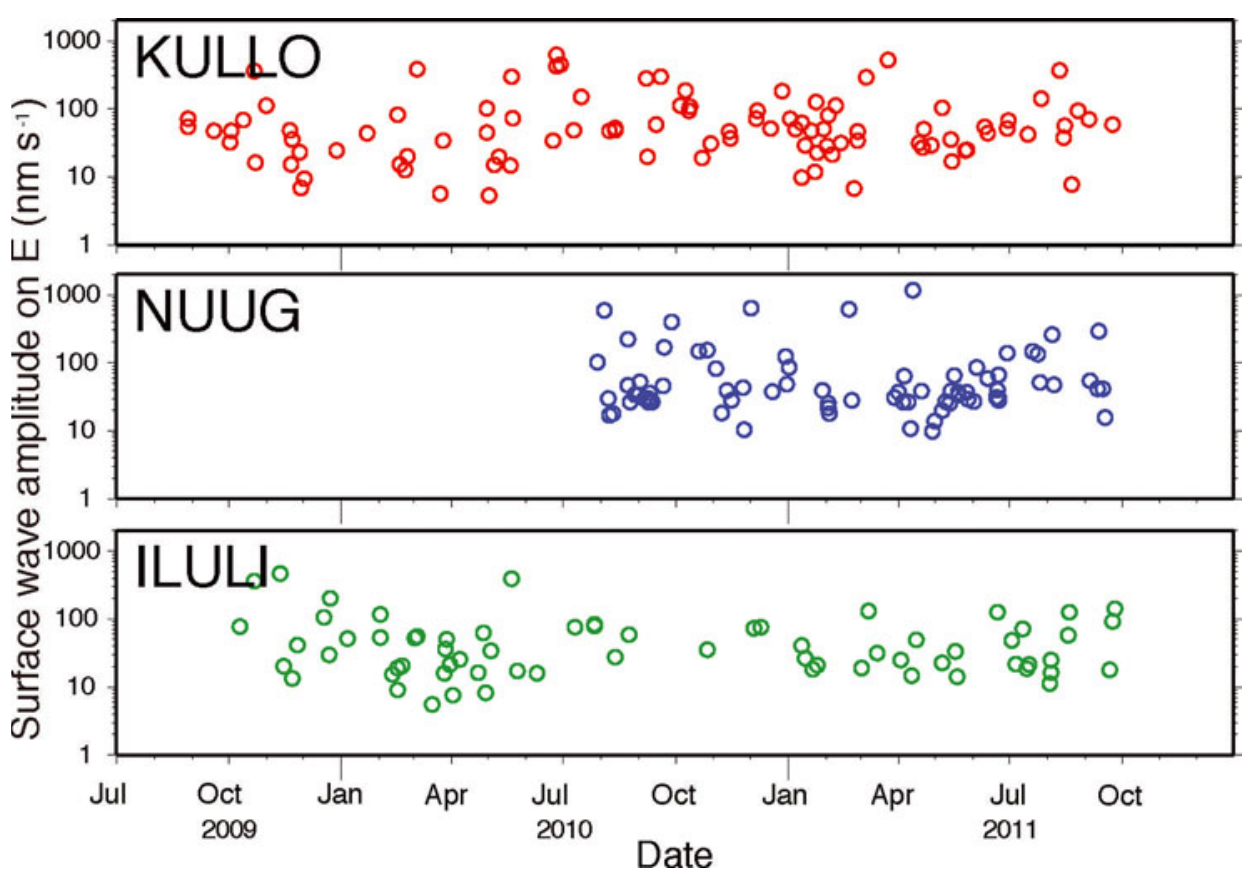

Fig. 8. Maximum amplitudes on east (E)-component calving seismograms in the $0.0167-0.033 \mathrm{~Hz}$ range (long-period surface wave energy), for all calving events in the manual catalogue. In contrast to the seiche signal amplitudes (Fig. 7), no seasonal variation is apparent in the surface wave amplitude at any station.

\subsection{Changing seismic background noise}

In order to understand whether our detection threshold was being influenced by variations in seismic noise, we followed the method of Vila and others (2006). We measure seismic background noise levels in the seiche $(0.001-0.01 \mathrm{~Hz})$ and low-frequency surface wave $(0.02-0.05 \mathrm{~Hz})$ frequency range for the three stations over the entire available dataset. To estimate the noise for each day, the average amplitude of the bandpassed velocity signal over a 3 hour time window is computed, and then the minimum 3 hour average amplitude value for each day is selected. Selecting a 3 hour period to estimate noise removes transient spikes from, for example, earthquakes that may occur elsewhere in the day, but also provides a fair indication of the average background noise, rather than the minimum. We can compare this noise measure with the recorded peak seiche amplitudes. Figure 10 shows that in both frequency ranges, the events detected by our method generally carry energy significantly above our measure of background noise. Exceptions are the LHN components of NUUG and KULLO.

We can draw several specific conclusions from Figure 10: First, the noise level of the horizontal components generally exceeds the noise on the vertical components by an order of magnitude. Thus, calving seismograms on the vertical component, on which our STA/LTA detector operates, have the best signal-to-noise ratio due to the low noise levels on these components. Second, there exist noise variations on a seasonal timescale in both the seiche and surface wave bands. On the other hand, the NUUG record shows that a peak in seiche detections does not coincide with the annual minimum in background noise. The last point, in particular, indicates that the seasonality in seiche detections at NUUG (Fig. 5) is not an artefact of seasonal changes in background noise levels. Concerning the reason for seasonal noise level variations we note that they are most evident on the horizontal components of ILULI and KULLO and have a similar phase in both frequency ranges, with noise minima and maxima occurring in the first and second half of 2010, respectively. Though it is possible that the noise is associated with external factors, we believe there may be a more simple explanation. The seismometers at these two sites are placed under residential buildings, as although the ambient noise is high, the sites are secure, protected from the elements and provide power and communications. Occupation is subject to weather conditions as well as human habit.

\subsection{Comparison with global surface wave detector}

Our calving detection catalogue (manually confirmed detections) consists of 257 events. This includes nine of the ten events detected as glacial earthquakes by teleseismic surface wave detection (nine detections at Jakobshavn Isbræ and one detection at Rink Isbræ; Veitch and Nettles, 2012) during the same time period and within the same regions. The single missed event occurred on Jakobshavn Isbræ on 21 May 2010; the seiche detector rejected the event because the seiche duration of $300 \mathrm{~s}$ is well below the discrimination threshold (1200s), and the seiche amplitude is small.

The large discrepancy in number of teleseismic surface wave detections and local seiche detections indicates that the second approach is significantly more sensitive. It should be noted that observed glacial earthquakes in the Veitch and Nettles (2012) catalogue are close to the glacial earthquake detection threshold. For instance, during a 50 day period in 2007, Nettles and others (2008) report six automatic glacial earthquake detections at Helheim Glacier, East Greenland, with magnitudes of 4.5-4.8. However, a more sensitive, interactive detection method identified five additional events. Another reason may be that the generation of glacial earthquakes during iceberg calving is more dependent on calving style and terminus geometry than is the generation of seiches. Specifically, in order to generate sufficient energy for detection as a glacial earthquake, it appears necessary 
that capsizing icebergs collide with the glacier terminus or fjord bottom (Amundson and others, 2008; Tsai and others, 2008; Nettles and Ekström, 2010; Walter and others, 2012). Iceberg calving from floating termini likely transfers less low-frequency surface wave energy into the solid Earth (Nettles and Ekström, 2010), and likely inhibits the detection of calving from floating termini using this method. In this context it is interesting to note that between 2008 and 2010 no glacial earthquakes were detected at Alison Glacier, near KULLO (Veitch and Nettles, 2012). The reason may be that from 2009 the calving front was afloat, and calving of tabular, non-capsizing icebergs became the predominant mechanism (Veitch and Nettles, 2012). On the other hand, we continue to observe calving seiches at KULLO during this period (Figs 5 and 6), and Alison Glacier likely produces a substantial fraction of these events.

By targeting an entirely independent physical mechanism, our seiche detector can serve as a complement to, and verification of, existing seismic detections of iceberg calving. It remains to be shown to what extent seiches can be generated by calving of non-capsizing icebergs (e.g. tabular icebergs calving from floating tongues). If sensitive to tabular iceberg calving, our detection scheme may find events which at distances of tens of $\mathrm{km}$ are more difficult to identify with higher-frequency detectors. At the same time, seiches could be generated by freely floating icebergs, which capsize in the middle of the fjord and may produce false detection in our calving catalogue. At least occasionally, such spontaneous capsizing can occur, and it can generate a typical high-frequency $(>2 \mathrm{~Hz})$ calving signature (Amundson and others, 2010). These cases may be responsible for at least part of the discrepancy between our catalogue at ILULI and the updated version of the catalogue by Amundson and others (2012a). However, if and how often such spontaneous capsizing events can 'falsely' trigger our seiche detection algorithm should be systematically investigated using satellite images.

If the magnitudes of the teleseismic surface wave detections and seiche amplitudes scaled with calving volume, for example, one would expect a clear, perhaps even linear, relationship between the amplitude of the lowfrequency surface waves and seiche signals at the local station. Figure 11 suggests that this is not necessarily the case: on the east-west component, only a weak trend between the two signal amplitudes exists, with some of the strongest (weakest) seiche signals associated with some of the strongest (weakest) surface wave amplitudes. The absence of a clearer relationship is not surprising considering that the relationship between low-frequency surface wave signals and volumes of detaching icebergs is likely complicated. Hydrodynamic drag forces and melange cover play an important role in the generation of contact forces between detaching icebergs and the glacier terminus, which in turn can cause significant lowfrequency surface wave energy (Tsai and others, 2008; Amundson and others, 2012b; Walter and others, 2012). Accordingly, more theoretical analysis is needed in order to accurately link centroid single force amplitudes (Ekström and others, 2003) to calving volumes. Similarly, one should investigate the influence of hydrodynamic drag forces on seiche amplitudes.

An open question and interesting prospect for future work therefore concerns the existence of a clear physical relationship between the observed seiche characteristics and calved

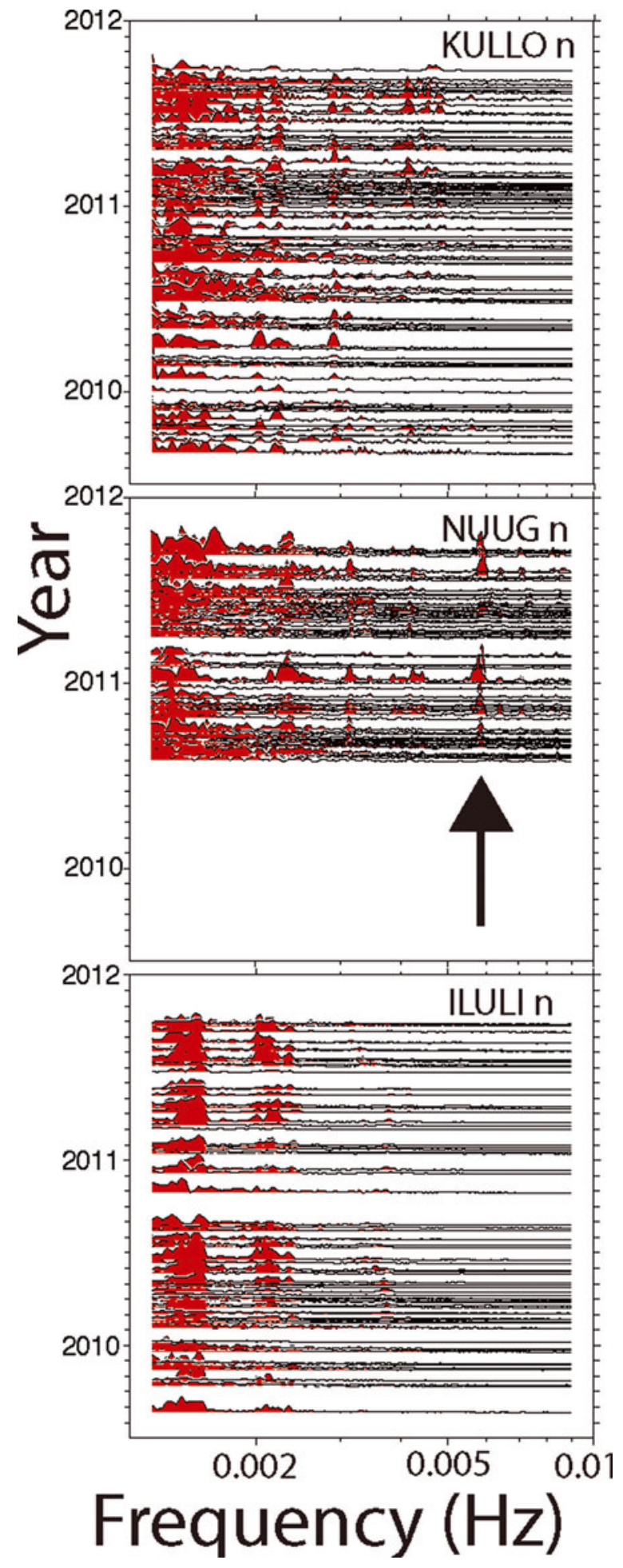

Fig. 9. Spectra from seiche seismograms for all calving events in the manual catalogue. Waveforms have instrument response removed. North (n) components are shown. Events are sorted by date of occurrence. Note the relative amplitudes and periods of spectral peaks vary over time. At NUUG, the peak at $0.006 \mathrm{~Hz}$ (black arrow) has dramatic changes in amplitudes. At ILULI, the fundamental frequency peak appears to lie closer to 0.003 in late summer and 0.004 in late winter.

iceberg properties such as location, volume or style of calving. Our catalogue indicates there are considerable variations in seiche amplitude, with little correlation with low-frequency seismic surface wave amplitude. Future investigations should aim to establish a physical meaning 

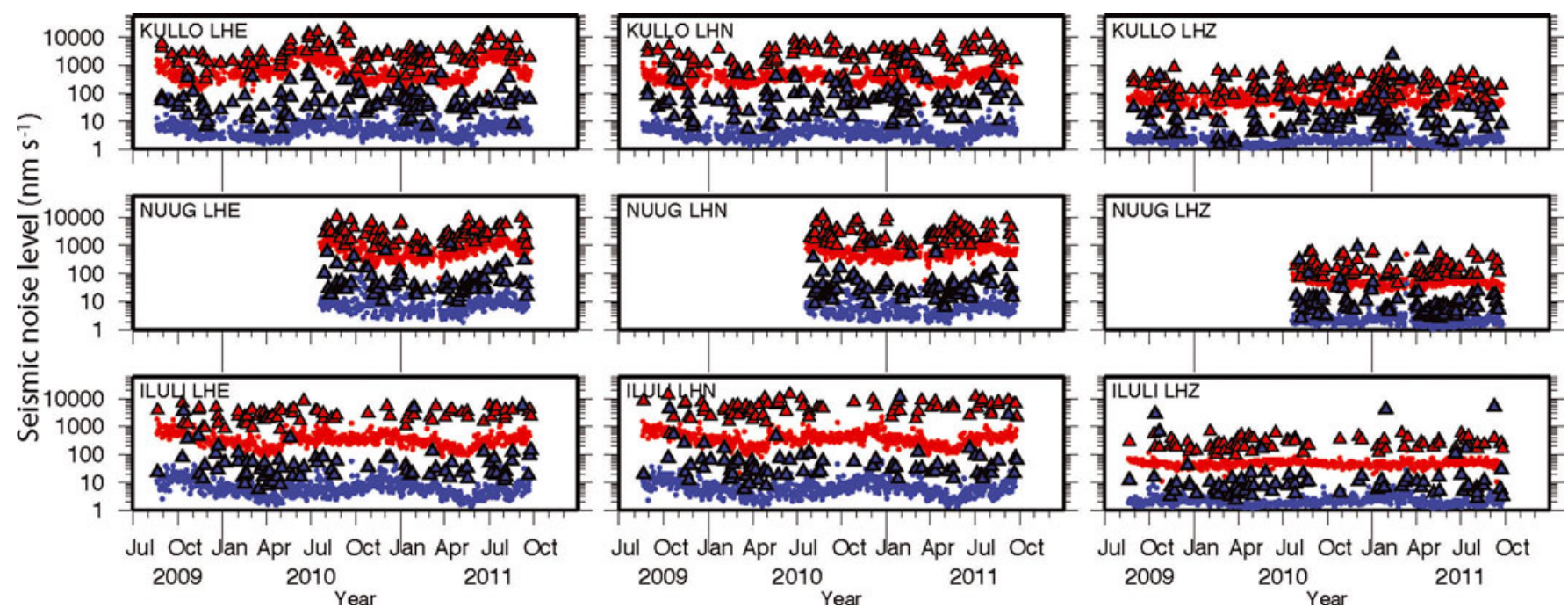

Fig. 10. Average daily seismic noise levels in the seiche frequency $(0.001-0.01 \mathrm{~Hz}$; red) and surface wave frequency $(0.02-0.05 \mathrm{~Hz}$; blue) bands at ILULI, NUUG and KULLO. Triangles indicate the maximum amplitudes of calving seismograms in the manual catalogue in the same respective frequency band. The algorithm detects calving events using the vertical component, and though the amplitude of the signal tends to be smaller than the horizontal component because the noise is substantially lower, the signal to noise is most favourable on this component.

for seiche signal characteristics, such as maximum amplitude, durations and dominant frequency. This would mean that monitoring calving-induced seiches could provide additional quantitative monitoring of calving volume.

\section{CONCLUSION AND OUTLOOK}

The present investigation demonstrates that fjord seiche detection can be used to identify and monitor calving events in northwest Greenland. Seiching events are clearly visible as tilt signals on broadband seismometers located near the

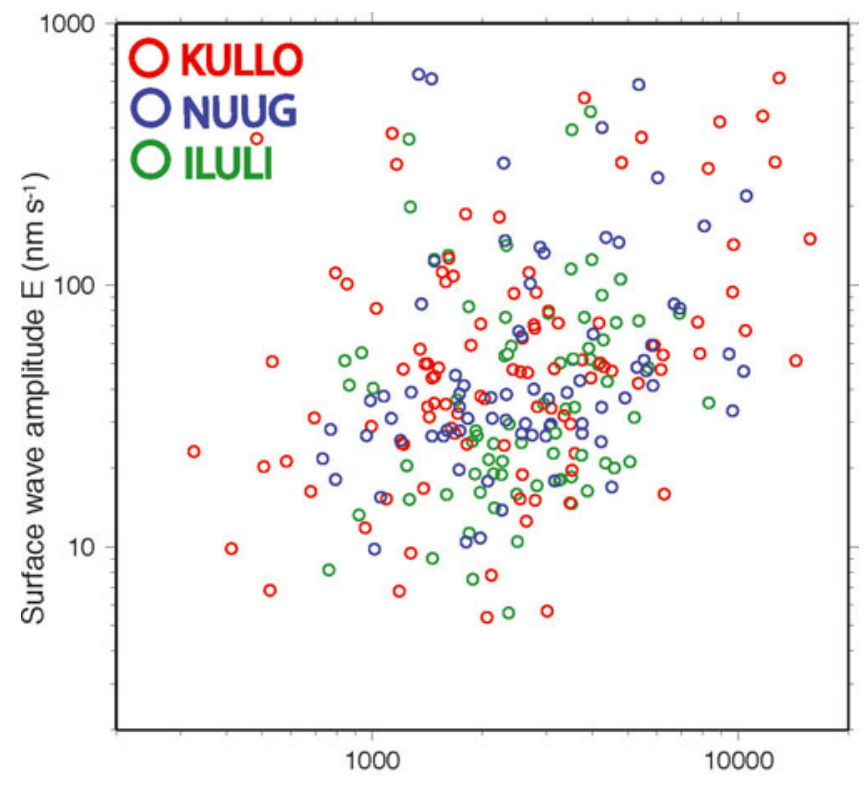

Amplitude of seiche seismogram $E\left(\mathrm{~nm} \mathrm{~s}^{-1}\right)$

Fig. 11. Comparison between amplitudes of surface wave $(0.0167-$ $0.033 \mathrm{~Hz})$ and seiche signals $(0.0012-0.007 \mathrm{~Hz})$ at each of the three stations. East (E) component is shown. There is no clear correlation between the amplitudes of seiche and surface wave signals at any of the locations. shoreline in the vicinity (within $100 \mathrm{~km}$ ) of calving fronts. At this point, the most reliable seiche-based calving catalogue can only be attained after visual review of continuous seismic records and the output of trigger algorithms. However, although the numbers of missed events and false detections given by our automatic detector can be considerable and at certain times dominant, the presented results nevertheless indicate that real-time seismic monitoring of major iceberg discharge events with little or no user interaction is, in principle, possible. In its current state, the automatic catalogue is already capable of highlighting qualitative aspects of calving activity in a specific region, such as the seasonal fluctuations near NUUG (Fig. 5). According to our background noise analysis, this pattern cannot be attributed to seasonal changes in trigger sensitivity. Consequently, the automatic catalogue could already be used as a monitoring tool to identify transient and long-term changes in calving activity.

Nevertheless, at this point, instrumental and/or site noise inhibits reliable detection records at one particular station, KULLO. Incorporating more sophisticated waveform recognition techniques will likely mitigate this problem and significantly improve the overall performance of our detection algorithm. This may also allow inclusion of additional seismic signals associated with iceberg calving such as high-frequency $(>1 \mathrm{~Hz})$ seismicity and long-period (35-150 s) surface wave energy. Another possibility would be to include other features of seiche seismograms, such as polarization and relative heights of spectral peaks.

The calving catalogue for NUUG identified seasonal fluctuations in calving activity at the glaciers in the Uummannaq district (Fig. 1). One explanation could be the previously reported seasonal fluctuations in terminus positions (Howat and others, 2010). For Jakobshavn Isbræ, the occurrence of events throughout the year at ILULI is consistent with the observation that the glacier had started to calve in winter as previously suggested by other workers (e.g. Fahnestock and others, 2010; Podrasky and others, 2012). These observations indicate that seismic monitoring of calving activity using seiche signals can serve as a means 
to study changes in glacier dynamics, which have been attracting much scientific attention, especially in Greenland.

The present seiche detection technique should be extended to incorporate more GLISN stations at the periphery of the Greenland ice sheet. At the same time, it will be important to establish relationships between physical iceberg parameters and seiche duration, amplitude and frequency content. High-resolution satellite images and denser networks of seismometers and fjord pressure sensors will be a valuable tool for this task. Ideally, this will allow for identification of various calving styles and estimation of calving volumes, which are difficult to quantify with existing methods.

\section{ACKNOWLEDGEMENTS}

Data used in this project are collected and distributed by the Greenland Ice Sheet Monitoring Network (GLISN). Funding for the installation of the three GLISN stations (KULLO, ILULI, NUUG) was provided by the Swiss National Science Foundation (200021-113503/1). These three stations are now maintained by the Swiss Seismological Service (SED) at ETH Zürich. We thank Domenico Giardini and the Electronics Laboratory, in particular Robin Hansemann, Franz Weber, Sacha Barmann and Peter Zweifel, for station design and installation. Trine Dahl-Jensen and Tine Larsen, of the Geological Survey of Denmark and Greenland (GEUS), and Trygve Marthinson, Joergen Thude, Barbara Stroem-Baris and Sven Nielsen provided crucial logistical support during the installation. We are indebted to Remy Jensen and his sons who against all odds found our missing pressure gauge in the ice fjord off Nuugaatsiaq. Jan Becker, of GEMPA, provided useful specific support for SeisComp3 configuration. We thank Martin Lüthi for providing fjord pressure data from station ILULF, and Jason Amundson for sharing an updated version of the calving record from Jakobshavn Isbræ. We acknowledge Leif Toudal Pedersen for the data processing of Envisat ASAR images (C) European Space Agency, provided by the Danish Meteorological Institute and the PolarView project. Thorough reviews by Meredith Nettles and Tim Bartholomaus substantially improved the scientific quality and readability of the manuscript.

\section{REFERENCES}

Allen RV (1978) Automatic earthquake recognition and timing from single traces. Bull. Seismol. Soc. Am., 68(5), 1521-1532

Alley RB and 7 others (2008) A simple law for ice-shelf calving. Science, 322(5906), 1344 (doi: 10.1126/science.1162543)

Amundson JM and Truffer M (2010) A unifying framework for iceberg-calving models. J. Glaciol., 56(199), 822-830 (doi: 10.3189/002214310794457173)

Amundson JM, Truffer M, Lüthi MP, Fahnestock M, West $M$ and Motyka RJ (2008) Glacier, fjord, and seismic response to recent large calving events, Jakobshavn Isbræ, Greenland. Geophys. Res. Lett., 35(22), L22501 (doi: 10.1029/2008GL035281)

Amundson JM, Fahnestock M, Truffer M, Brown J, Lüthi MP and Motyka RJ (2010) Ice melange dynamics and implications for terminus stability, Jakobshavn Isbræ, Greenland. J. Geophys. Res., 115(F1), F01005 (doi: 10.1029/2009JF001405)

Amundson JM, Clinton JF, Fahnestock M, Truffer M, Lüthi MP and Motyka RJ (2012a) Observing calving-generated ocean waves with coastal broadband seismometers, Jakobshavn Isbræ, Greenland. Ann. Glaciol., 53(60 Pt 1), 79-84 (doi: 10.3189/ 2012AoG60A200)

Amundson JM, Burton JC and Correa-Legisos SC (2012b) Impact of hydrodynamics on seismic signals generated by iceberg collisions. Ann. Glaciol., 53(60 Pt 1), 106-112 (doi: 10.3189/ 2012AoG60A012)

Bartholomaus TC, Larsen CF, O'Neel S and West M (2012) Calving seismicity from iceberg-sea surface interactions. J. Geophys. Res., 117(F4), F04029 (doi: 10.1029/2012JF002513)

Bassis JN (2011) The statistical physics of iceberg calving and the emergence of universal calving laws. J. Glaciol., 57(201), 3-16 (doi: 10.3189/002214311795306745)

Benn DI, Hulton NRJ and Mottram RH (2007) 'Calving laws', 'sliding laws' and the stability of tidewater glaciers. Ann. Glaciol., 46, 123-130 (doi: 10.3189/172756407782871161)

Bindschadler RA (1984) Jacobshavns Glacier drainage basin: a balance assessment. J. Geophys. Res., 89(C2), 2066-2072

Bondevik S, Løvholt F, Harbitz C, Mangerud J, Dawson A and Svendsen JI (2005) The Storegga Slide tsunami - comparing field observations with numerical simulations. Mar. Petrol. Geol., 22(1-2), 195-208

Bromirski PD and Stephen R (2012) Response of the Ross Ice Shelf to ocean gravity waves. Ann. Glaciol., 53(60 Pt 1), 163-172 (doi: 10.3189/2012AoG60A058)

Burton JC and 9 others (2012) Laboratory investigations of iceberg capsize dynamics, energy dissipation and tsunamigenesis. J. Geophys. Res., 117(F1), F01007 (doi: 10.1029/2011JF002055)

Cassotto RK, Fahnestock MA and Amundson JM (2010) Winter MODIS observations of West Greenland fjord ice activity. [Abstr. C51A-0472] Am. Geophys. Union, Fall Meet.

Chen X, Shearer PM, Walter F and Fricker HA (2011) Seventeen Antarctic seismic events detected by global surface waves and a possible link to calving events from satellite images. J. Geophys. Res., 116(B6), B06311 (doi: 10.1029/2011JB008262)

Clinton JF (2004) Modern digital seismology - instrumentation, and small amplitude studies for the engineering world. (PhD thesis, California Institute of Technology)

Dahl-Jensen D, Larsen TB, Voss PH and GLISN (2010) Greenland ice sheet monitoring network (GLISN): a seismological approach. Geol. Surv. Den. Greenl. Bull., 20, 55-58

Ekström G, Nettles M and Abers GA (2003) Glacial earthquakes. Science, 302(5645), 622-624 (doi: 10.1126/science.1088057)

Ekström G, Nettles M and Tsai VC (2006) Seasonality and increasing frequency of Greenland glacial earthquakes. Science, 311(5768), 1756-1758 (doi: 10.1126/science.1122112)

Fahnestock MA and 6 others. (2010) Changing seasonality of ice front position and calving in Jakobshavns Isbrae, West Greenland, in relation to drawdown history and character of fjord ice cover. [Abstr. C41B-02] Am. Geophys. Union, Fall Meet.

Forel FA (1904) Le Léman, monographie limnologique. Librarie de I'Université, Lausanne

Goldstein P, Dodge D, Firpo M and Minner L (2003) SAC 2000: signal processing and analysis tools for seismologists and engineers. Invited contribution to Lee WHK, Kanamori PC, Jennings PC and Kisslinger C, The ISPAEI international handbook of earthquake and engineering seismology. Academic Press, London

Grob M, Maggi A and Stutzmann E (2011) Observations of the seasonality of the Antarctic microseismic signal, and its association to sea ice variability. Geophys. Res. Lett., 38(11), L11302 (doi: 10.1029/2011GL047525)

Hanka W and 6 others (2010) Real-time earthquake monitoring for tsunami warning in the Indian Ocean and beyond. Natur. Hazards Earth Syst. Sci. (NHESS), 10(12), 2611-2622 (doi: 10.5194/nhess-10-2611-2010)

Holland DM, Thomas RH, de Young B, Ribergaard MH and Lyberth B (2008) Acceleration of Jakobshavn Isbræ triggered by warm subsurface ocean waters. Nature Geosci., 1(10), 659-664 (doi: 10.1038/ngeo316)

Howat IM and Eddy A (2011) Multi-decadal retreat of Greenland's marine-terminating glaciers. J. Glaciol., 57(203), 389-396 (doi: 10.3189/002214311796905631)

Howat IM, Box JE, Ahn Y, Herrington A and McFadden EM (2010) Seasonal variability in the dynamics of marine-terminating 
outlet glaciers in Greenland. J. Glaciol., 56(198), 601-613 (doi: 10.3189/002214310793146232)

Husen S, Clinton J, Olivieri M and Giardini D (2010) The Swiss Seismological Service in Greenland: network building and research initiatives. [Abstr. C43A-0526] Am. Geophys. Union, Fall Meet.

Ichinose G, Anderson J, Satake K, Schweikert R and Lahren M (2000) The potential hazard from tsunami and seiche waves generated by large earthquakes within Lake Tahoe, CaliforniaNevada. Geophys. Res. Lett., 27(8), 1203-1206 (doi: 10.1029/ 1999GL011119)

Joughin I (2006) Greenland rumbles louder as glaciers accelerate. Nature, 311(5768), 1719-1720 (doi: 10.1126/science.1124496)

Joughin I, Abdalati W and Fahnestock MA (2004) Large fluctuations in speed on Greenland's Jakobshavn Isbræ glacier. Nature, 432(7017), 608-610 (doi: 10.1038/nature03130)

Joughin I and 8 others (2008a) Ice-front variation and tidewater behavior on Helheim and Kangerdlugssuaq Glaciers, Greenland. J. Geophys. Res., 113(F1), F01004 (doi: 10.1029/2007JF000837)

Joughin I and 7 others (2008b) Continued evolution of Jakobshavn Isbrae following its rapid speedup. J. Geophys. Res., 113(F4), F04006 (doi: 10.1029/2008JF001023)

Joughin I, Smith BE, Howat IM, Scambos $\mathrm{T}$ and Moon $\mathrm{T}$ (2010) Greenland flow variability from ice-sheet-wide velocity mapping. J. Glaciol., 56(197), 415-430 (doi: 10.3189/ 002214310792447734)

Khan SA, Wahr J, Bevis M, Velicogna I and Kendrick E (2010) Spread of ice mass loss into northwest Greenland observed by GRACE and GPS. Geophys. Res. Lett., 37(6), L06501 (doi: 10.1029/2010GL042460)

Köhler A, Chapuis A, Nuth C, Kohler J and Weidle C (2011) Seasonal variations of glacier dynamics at Kronebreen, Svalbard revealed by calving related seismicity. Cryos. Discuss., 5(6), 3291-3321

Krabill W and 12 others (2004) Greenland Ice Sheet: increased coastal thinning. Geophys. Res. Lett., 31(24), L24402 (doi: 10.1029/2004GL021533)

Kvale A (1955) Seismic seiches in Norway and England during the Assam earthquake of August 15, 1950. Bull. Seismol. Soc. Am., 45(2), 93-113

Larmat C, Tromp J, Liu Q and Montagner J-P (2008) Time reversal location of glacial earthquakes. J. Geophys. Res., 113(B9), B09314 (doi: 10.1029/2008JB005607)

Lee J-J (1971) Wave-induced oscillations in harbours of arbitrary geometry. J. Fluid Mech., 45(2), 375-394

Luckman A and Murray T (2005) Seasonal variation in velocity before retreat of Jacobshavn Isbræ, Greenland. Geophys. Res. Lett., 32(8), L08501 (doi: 10.1029/2005GL022519)

Lüthi MP (2009) Terminus geometry as main control on outlet glacier velocity. Geophys. Res. Abstr., 11, EGU2009-6862

MacAyeal DR, Freed-Brown J, Zhang WW and Amundson JM (2012) The influence of ice melange on fjord seiches. Ann. Glaciol., 53(60 Pt 1), 45-49 (doi: 10.3189/2012AoG60A027)

McFadden EM, Howat IM, Joughin I, Smith BE and Ahn Y (2011) Changes in the dynamics of marine terminating outlet glaciers in west Greenland (2000-2009). J. Geophys. Res., 116(F2), F02022 (doi: 10.1029/2010JF001757)

McNamara DE, Ringler AT, Hutt CR and Gee LS (2011) Seismically observed seiching in the Panama Canal. J. Geophys. Res., 116(B4), B04312 (doi: 10.1029/2010JB007930)

Miles JW (1974) Harbor seiching. Annu. Rev. Fluid Mech., 6, 17-33

Moon T and Joughin I (2008) Changes in ice front position on Greenland's outlet glaciers from 1992 to 2007. J. Geophys. Res., 113(F2), F02022 (doi: 10.1029/2007JF000927)

Moon T, Joughin I, Smith B and Howat I (2012) 21st-century evolution of Greenland outlet glacier velocities. Science, 336(6081), 576-578 (doi: 10.1126/science.1219985)

Motyka RJ, Hunter L, Echelmeyer KA and Connor C (2003) Submarine melting at the terminus of a temperate tidewater glacier, LeConte Glacier, Alaska, U.S.A. Ann. Glaciol., 36, 57-65 (doi: 10.3189/172756403781816374)
Murray T and 10 others (2010) Ocean regulation hypothesis for glacier dynamics in southeast Greenland and implications for ice sheet mass changes. J. Geophys. Res., 115(F3), F03026 (doi: 10.1029/2009JF001522)

Nettles M and Ekström G (2010) Glacial earthquakes in Greenland and Antarctica. Annu. Rev. Earth Planet. Sci., 38, 467-491 (doi: 10.1146/annurev-earth-040809-152414)

Nettles M and 12 others (2008) Step-wise changes in glacier flow speed coincide with calving and glacial earthquakes at Helheim Glacier, Greenland. Geophys. Res. Lett., 35(24), L24503 (doi: 10.1029/2008GL036127)

Nick FM, Vieli A, Howat IM and Joughin I (2009) Large-scale changes in Greenland outlet glacier dynamics triggered at the terminus. Nature Geosci., 2(2), 110-114 (doi: 10.1038/ ngeo394)

O'Neel S and Pfeffer WT (2007) Source mechanics for monochromatic icequakes produced during iceberg calving at Columbia Glacier, AK. Geophys. Res. Lett., 34(22), L22502 (doi: 10.1029/ 2007GL031370)

O'Neel S, Marshall HP, McNamara DE and Pfeffer WT (2007) Seismic detection and analysis of icequakes at Columbia Glacier, Alaska. J. Geophys. Res., 112(F3), F03S23 (doi: 10.1029/2006JF000595)

O'Neel S, Larsen CF, Rupert N and Hansen R (2010) Iceberg calving as a primary source of regional-scale glacier-generated seismicity in the St. Elias Mountains, Alaska. J. Geophys. Res., 115(F4), F04034 (doi: 10.1029/2009JF001598)

Okal EA (2007) Seismic records of the 2004 Sumatra and other tsunamis: a quantitative study. Pure Appl. Geophys., 164(2-3), 325-353 (doi: 10.1007/s00024-006-0181-4)

Pino NA (2012) Post-seismic relaxation following the 2009 April 6, L'Aquila (Italy), earthquake revealed by the mass position of a broad-band seismometer. Geophys. J. Int., 189(3), 1717-1724 (doi: 10.1111/j.1365-246X.2012.05450.x)

Podrasky D, Fahnestock M, Amundson J, Cassotto R and Joughin I (2012) Outlet glacier response to forcing over hourly to international timescales, Jakobshavn Isbræ, Greenland. J. Glaciol., $\mathbf{5 8}(212), 1212-1226$

Pritchard HD, Arthern RJ, Vaughan DG and Edwards LA (2009) Extensive dynamic thinning on the margins of the Greenland and Antarctic ice sheets. Nature, 461(7266), 971-975 (doi: 10.1038/nature08471)

Qamar A (1988) Calving icebergs: a source of low-frequency seismic signals from Columbia Glacier, Alaska. J. Geophys. Res., 93(B6), 6615-6623 (doi: 10.1029/JB093iB06p06615)

Richardson JP, Waite GP, FitzGerald KA and Pennington WD (2010) Characteristics of seismic and acoustic signals produced by calving, Bering Glacier, Alaska. Geophys. Res. Lett., 37(3), L03503 (doi: 10.1029/2009GL041113)

Rignot E and Kanagaratnam P (2006) Changes in the velocity structure of the Greenland Ice Sheet. Science, 311(5673), 986-990 (doi: 10.1126/science.1121381)

Rignot E, Box JE, Burgess E and Hanna E (2008) Mass balance of the Greenland ice sheet from 1958 to 2007. Geophys. Res. Lett., 35(20), L20502 (doi: 10.1029/2008GL035417)

Rignot E, Koppes M and Velicogna I (2010) Rapid submarine melting of the calving faces of West Greenland glaciers. Nature Geosci., 3(3), 141-218 (doi: 10.1038/ngeo765)

Rignot E, Velicogna I, Van den Broeke MR, Monaghan A and Lenaerts J (2011) Acceleration of the contribution of the Greenland and Antarctic ice sheets to sea level rise. Geophys. Res. Lett., 38(5), L05503 (doi: 10.1029/2011GL046583)

Rignot E, Fenty I, Menemenlis D and Xu Y (2012) Spreading of warm ocean waters around Greenland as a possible cause for glacier acceleration. Ann. Glaciol., 53(60 Pt 2), 257-266 (doi: 10.3189/2012AoG60A136)

Sohn HG, Jezek KC and Van der Veen CJ (1998) Jakobshavn Glacier, West Greenland: 30 years of spaceborne observations. Geophys. Res. Lett., 25(14), 2699-2702 (doi: 10.1029/ 98GL01973) 
Spada G, Ruggieri G, Sørensen LS, Nielsen K, Melini D and Colleoni F (2012) Greenland uplift and regional sea level changes from ICESat observations and GIA modeling. Geophys. J. Int., 189(3), 1457-1474 (doi: 10.1111/j.1365-246X.2012.05443.x)

Thomas RH (2004) Force-perturbation analysis of recent thinning and acceleration of Jakobshavn Isbræ, Greenland. J. Glaciol., 50(168), 57-66 (doi: 10.3189/172756504781830321)

Thomas RH, Abdalati W, Frederick E, Krabill WB, Manizade S and Steffen K (2003) Investigation of surface melting and dynamic thinning on Jakobshavn Isbræ, Greenland. J. Glaciol., 49(165), 231-239 (doi: 10.3189/172756503781830764)

Truffer M, Amundson JM, Fahnestock MA, Motyka R and Joughin IR (2010) How do oceans regulate ice flow? [Abstr. C42A-08] Am. Geophys. Union, Fall Meet.

Tsai VC and Ekström G (2007) Analysis of glacial earthquakes. J. Geophys. Res., 112(F3), F03522 (doi: 10.1029/ 2006JF000596)

Tsai VC and McNamara DE (2011) Quantifying the influence of sea ice on ocean microseism using observations from the Bering Sea, Alaska. Geophys. Res. Lett., 38(22), L22502 (doi: 10.1029/ 2011GL049791)
Tsai VC, Rice JR and Fahnestock M (2008) Possible mechanisms for glacial earthquakes. J. Geophys. Res., 113(F3), F03014 (doi: 10.1029/2007JF000944)

Van den Broeke $M$ and 8 others (2009) Partitioning recent Greenland mass loss. Science, 326(5955), 984-986 (doi: 10.1126/science.1178176)

Veitch SA and Nettles M (2012) Spatial and temporal variations in Greenland glacial-earthquake activity, 1993-2010. J. Geophys. Res., 117(F4) (doi: 10.1029/2012JF002412)

Vila J, Macià R, Kumar D, Ortiz R, Moreno $\mathrm{H}$ and Correiga AM (2006) Analysis of the unrest of active volcanoes using variations of the base level noise seismic spectrum. J. Volcanol. Geotherm. Res., 153(1-2), 11-20 (doi: 10.1016/j.jvolgeores.2005.10.011)

Walter F, Amundson JM, O'Neel S, Truffer $M$ and Fahnestock $M$ (2012) Analysis of low-frequency seismic signals generated during a multiple-iceberg calving event at Jakobshavn Isbræ, Greenland. J. Geophys. Res., 117(F1) (doi: 10.1029/ 2011JF002055)

Wieldant E and Forbriger T (1999) Near-field seismic displacement and tilt associated with the explosive activity of Stromboli. Ann. Geof., 42(3) (doi: 10.4401/ag-3723)

\section{APPENDIX}

Table 3. Manual catalogue of calving events from the seiche detector. For station ILULI, all detections indicate calving activity at Jakobshavn Isbræ, as it is the only major ice stream nearby. ' $\mathrm{A}$ ' and ' $\mathrm{VN}$ ', respectively, indicate that the detections are also part of the updated Amundson and others (2012a) and Veitch and Nettles (2012) catalogues

ILULI NUUG NULLO

2009-08-21 07:14 A VN

2009-10-10 11:53 A

2009-10-13 05:55

2009-10-22 01:25

2009-11-12 14:14

2009-11-15 12:56 A

2009-11-22 07:55

2009-11-26 00:43

2009-12-18 16:45 A

2009-12-22 19:35 A

2009-12-23 13:39

2010-01-06 15:32

2010-02-02 14:41 A

2010-02-02 23:17

2010-02-12 17:28 A

2010-02-16 09:52 A

2010-02-16 18:34 A

2010-02-20 07:02 A

2010-02-21 04:23 A,VN

2010-03-02 05:56

2010-03-04 10:59

2010-03-16 00:36 A

2010-03-19 01:24 A,VN

2010-03-26 09:25 A

2010-03-27 06:08 A

2010-03-28 04:36 A

2010-03-31 02:36 A

2010-04-02 02:14

2010-04-08 02:00

2010-04-14 14:24 A,VN

2010-04-23 01:05

2010-04-27 03:41 A

2010-04-29 03:09

2010-05-03 14:44 A

2010-05-20 22:31 A

2010-05-25 07:12 A

2010-05-27 11:35 A,VN

2010-06-10 19:08 A

2010-06-17 09:36 A,VN
2010-07-29 06:11

2010-08-04 07:54

2010-08-07 03:44

2010-08-08 08:21

2010-08-11 12:41

2010-08-23 03:32

2010-08-23 04:00

2010-08-25 21:03

2010-08-29 05:58

2010-09-01 17:04

2010-09-02 23:11

2010-09-06 21:13

2010-09-09 09:53

2010-09-09 20:44

2010-09-10 06:07

2010-09-12 08:47

2010-09-21 16:12

2010-09-22 16:46

2010-09-28 19:57

2010-10-20 22:06

2010-10-27 01:57 VN

2010-11-03 08:17

2010-11-07 09:57

2010-11-08 02:43

2010-11-12 06:21

2010-11-16 06:38

2010-11-25 11:53

2010-11-26 05:35

2010-12-02 03:47

2010-12-19 23:42

2010-12-30 00:39

2010-12-31 19:43

2011-01-02 04:53

2011-01-29 19:42

2011-02-03 06:33

2011-02-03 18:44

2011-02-04 04:22

2011-02-20 22:01

2011-02-22 16:28
2009-08-29 02:38

2009-08-29 14:28

2009-09-19 23:28

2009-10-02 22:32

2009-10-03 05:00

2009-10-13 18:19

2009-10-22 20:15

2009-10-23 21:11

2009-11-01 13:35

2009-11-20 18:27

2009-11-21 17:04

2009-11-22 18:22

2009-11-28 05:43

2009-11-29 18:03

2009-12-02 11:28

2009-12-28 21:58

2010-01-22 22:54

2010-02-16 23:25

2010-02-18 18:13

2010-02-22 04:04

2010-02-24 06:20

2010-03-04 14:41

2010-03-23 13:00

2010-03-25 10:10

2010-04-30 00:39

2010-04-30 14:14

2010-05-02 07:12

2010-05-06 22:48

2010-05-10 07:46

2010-05-19 14:21

2010-05-20 22:51

2010-05-21 23:23

2010-06-23 14:09

2010-06-26 13:57

2010-06-26 15:52

2010-06-29 21:11

2010-07-10 22:05

2010-07-16 19:35

2010-07-17 04:46 
Table 3. continued

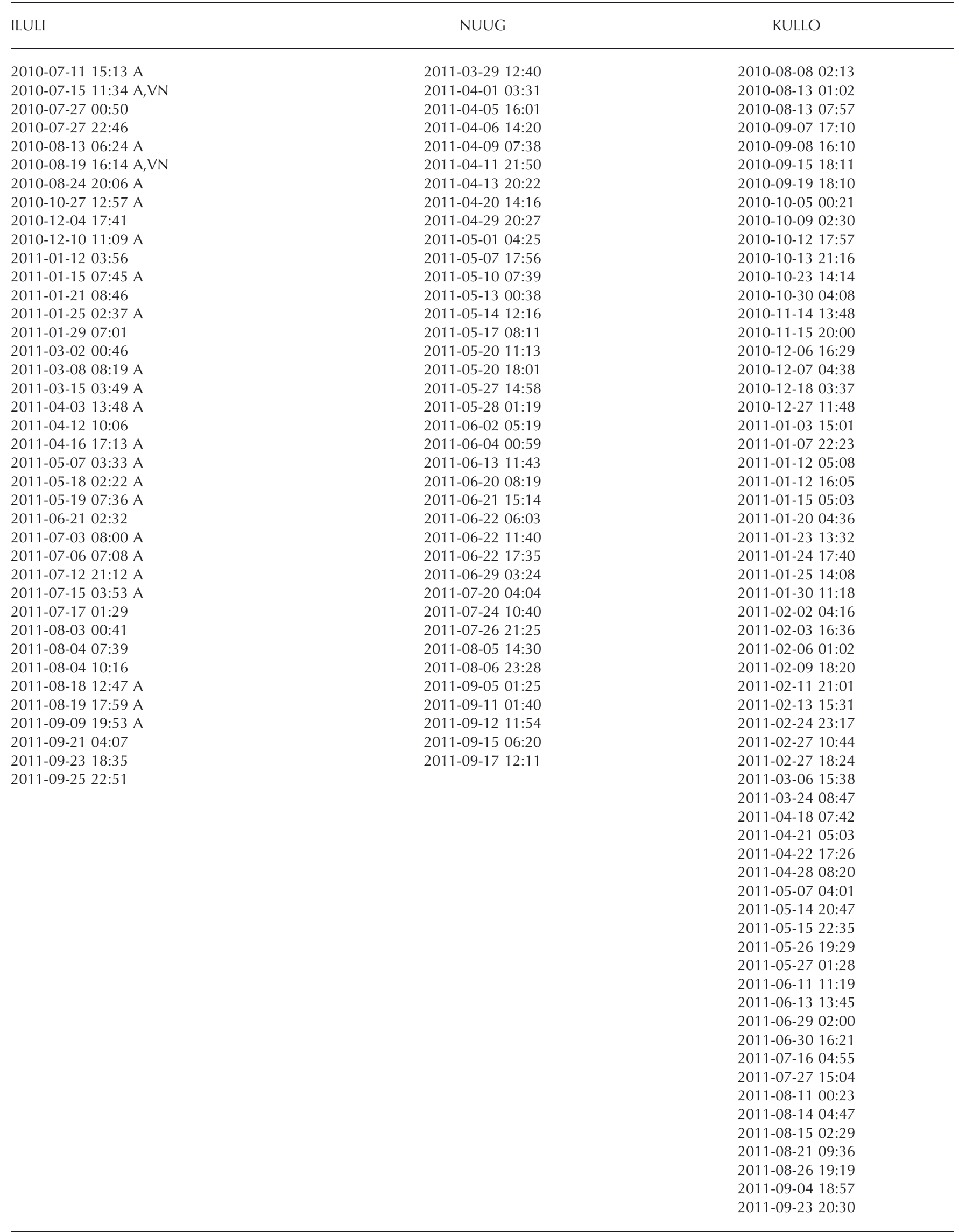

